\title{
Quality assessment and hydrochemistry of a coastal aquifer adjacent to a hypersaline lake: $A$ case study of Western Asia
}

Majid Bahramian ( $\square$ majid.bahramian@ucd.ie)

University College Dublin https://orcid.org/0000-0002-7571-5567

Mojtaba Bahramian

Ministry of Environment Water and Climate

Kaan Yetilmezsoy

Yildiz Technical University: Yildiz Teknik Universitesi

\section{Research Article}

Keywords: Hydrochemistry, Groundwater quality, Hypersaline lake, Salinity, Spatial distribution

Posted Date: July 31st, 2021

DOI: https://doi.org/10.21203/rs.3.rs-181736/v1

License: (c) (i) This work is licensed under a Creative Commons Attribution 4.0 International License.

Read Full License 


\title{
Quality assessment and hydrochemistry of a coastal aquifer adjacent to a hypersaline lake: A case study of Western Asia
}

\author{
Majid Bahramian ${ }^{1,3,}$, Mojtaba Bahramian², Kaan Yetilmezsoy ${ }^{3}$
}

${ }^{1}$ School of Chemical and Bioprocess Engineering, University College Dublin, Priesthouse, Dublin, Ireland

${ }^{2}$ Ministry of Industry, Mine and Trade, Tabriz, Iran

${ }^{3}$ Department of Environmental Engineering, Faculty of Civil Engineering, Yildiz Technical University, Davutpasa Campus, 34220, Esenler, Istanbul, Turkey

E-mail addresses:

majid.bahramian@std.yildiz.edu.tr; majidbahramian401@gmail.com (Majid Bahramian) m.b.msc.miner@gmail.com (Mojtaba Bahramian)

yetilmez@yildiz.edu.tr; kyetilmezsoy@gmail.com (Kaan Yetilmezsoy)

*Corresponding author: Majid Bahramian

E-mail addresses: majid.bahramian@std.yildiz.edu.tr; majidbahramian401@gmail.com

\section{ORCID}

Majid Bahramian (D) https://orcid.org/0000-0002-7571-5567

Mojtaba Bahramian (D) https://orcid.org/0000-0002-6400-5818

Kaan Yetilmezsoy (D) http://orcid.org/0000-0003-1478-9957 


\section{Abstract}

The study is motivated by the quality degradation of groundwater with emphasis on salinity between 2012 and 2018 in an aquifer, namely Azarshahr aquifer, located in Western Asia (a case of north-west of Iran), adjacent to Lake Urmia. The groundwater of Azarshahr plain in the southeast, namely, the nutritional zone of the plain, has a low amount of salts $(0.7-18.06 \mathrm{mg} / \mathrm{L})$, but by moving to the north-west and west of the plain, which is the location of the outflow of water, the concentration of salts is significantly increased $(35.42-87.5 \mathrm{mg} / \mathrm{L}) . \mathrm{Ca}-\mathrm{Cl}$ has the cardinal influence on quality of water, making it different from the common type of fresh waters in Iran $\left(\mathrm{Ca}-\mathrm{HCO}_{3}\right)$. High concentrations of $\mathrm{SO}_{4}{ }^{2-}, \mathrm{Cl}^{-}$, and $\mathrm{Na}^{+}$detected in almost all the water samples, which indicates aquifer's good quality for portable applications. Regarding agricultural applications, from 2012 to 2018, the percentage of samples in the good class of C2S1 has been reduced by $35 \%$, which could also be a further indicator of increasing salinity in the aquifer. The spatial distribution of electrical conductivity (EC), cations, and anions tends to follow an increasing pattern toward western regions. Comparing the results of hydrochemical analysis of Lake Urmia with the corresponding results from the groundwater in Azarshahr plain, there is an acceptable correlation between the hydrochemical features of Lake Urmia with the saltwater of western parts of the Azarshahr plain. Hence, it is likely that another source of water salination in this plain, especially in western parts, is the influx from Urmia Lake. Due to the presence of clay mass of mountains between the Lake Urmia and Azarshahr plain as well as the lack of a hydraulic relationship, the probability of penetration of saline water from reinforced water reservoirs of Lake Urmia to the aquifer of Azarshahr plain is further strengthened.

Keywords: Hydrochemistry; Groundwater quality; Hypersaline lake, Salinity; Spatial distribution 


\section{Introduction}

Industrial development accompanied by population growth has imposed heavy pollution loads to natural resources (Mehrdadi et al., 2006; Nasrabadi and Bidabadi, 2013; Rowshan et al., 2007). Water resource contamination is one of the major challenges in the way of sustainable development (Mehrdadi et al., 2006). From the total accessible fresh water all around the world more than $90 \%$ is contributed to groundwater resources (Petersen et al., 2017). Accordingly, sophisticated attention towards monitoring the quality and quantity of such resources would play a key role in achieving the global sustainable development in near future (Gerten et al., 2013).

During the past two decades, groundwater quality evaluations in different parts of the world have been studied by various researchers (Hu et al., 2019; Haidu and Nistor, 2019; Malov and Tokarev, 2019; Selvam et al., 2014; Pei-Yue et al., 2010; Melaku and Wang, 2019; Almeida et al., 2018). In this regard, Thirumalini and Joseph (2009) have examined various sampling wells to determine regression equation between electrical conductivity (EC) and total dissolved solids (TDS) for fresh water and saltwater in the Triuvallur district located on the northern border of Tamil Nadu, India. They reported that a linear correlation exists between these two parameters for fresh water, whereas there is a logarithmic correlation for saltwater. Shah et al. (2008) have compared groundwater quality in Gandhinagar Taluka in India with standard values described by World Health Organization (WHO, 2017) and have come up with a water quality index for that area.

Urmia Lake is one of the largest hyper-saline lakes in the world and the largest one in the Middle East (Gorgij et al., 2019). Once it was considered as the second largest hypersaline lake in the world, is suffering from sewer drought and saltwater intrusion. Ghale et al. (2017) reported that salty soil areas of the Lake Urmia have increased dramatically from 1995 to 2014 and more 
than $5000 \mathrm{~km}^{2}$ of Lake Urmia's water surface area was converted to salty soil bodies during recent years. Mardi et al. (2018) reported that the combined area of salt and salty soil bodies around Urmia Lake have increased by two orders of magnitude in the past two decades. Jeihouni et al. (2018) assessed the groundwater quantity over 11 years using a novel groundwater balance estimation method. The results indicated the negativity of the groundwater balance during this period which furthermore decreased the quality of the groundwater over the study period with the most severe condition in west and southwest of the study area. Shakerkhatibi et al. (2018) found that the total hardness of the groundwater in the region is highly correlated with the magnesium concentration than calcium. They reported that the dominant cations and anions in Lake Urmia were in the order of $\mathrm{Mg}^{2+}>\mathrm{Na}^{+}>\mathrm{Ca}^{2+}>\mathrm{K}^{+}$and $\mathrm{HCO}_{3}^{-}>\mathrm{SO}_{4}{ }^{2-}>\mathrm{Cl}^{-}>\mathrm{NO}_{3}^{-}>\mathrm{F}^{-}$, respectively. They also reported that the major water types in the area were fresh $\left(\mathrm{Ca}-\mathrm{HCO}_{3}\right)$ and saline $(\mathrm{Ca}-\mathrm{Mg}-\mathrm{Cl})$.

The need for water has produced an increasing withdrawal of groundwater in sensitive areas like deserts, where aquifers suffer from saline water intrusion, which consequently results in a deterioration of its quality (Arabameri et al., 2019). Groundwater salinization occurs in many aquifers around the world (Argamasilla et al., 2017; Moreau et al., 2019; Ferrer et al., 2019; Ponsadailakshmi et al., 2018; Vižintin et al., 2018; Bertrand et al., 2006). Understanding the origin and mechanisms of the salinization process is an important point for preventing further deterioration of groundwater resources. In the nature, elements such as radon and arsenic can leach into aquifers that have been drawn down (Amiri et al., 2014). Meanwhile, lowered levels of freshwater in the top layers of aquifers can also expose ponderous and non-buoyant saltwater to settle down which in longer time results in salinization of both ground water and any other adjacent water body. Temporal changes in the origin and constitution of the recharged water, 
hydrologic and human factors may cause periodic changes in groundwater quality (Reza and Singh, 2010).

Considering the relevant literature gap on the present subject, a hypothesis was defined to assess the suitability of the groundwater in Azarshahr aquifer for drinking and agricultural applications. Besides completing the information about groundwater quality in the Azarshahr aquifer, an assessment of the quality and hydrochemistry of an aquifer adjacent to a hypersaline lake was conducted. In this regard, the main objective of the present work was to provide a comprehensive assessment on the quality gradients of the groundwater in Azarshar aquifer in a period between 2012 and 2018.

\section{Materials and methods}

\section{Study area}

The study area is in the north-west of Iran, between the eastern longitude of $44^{\circ}, 20^{\prime}$ and $45^{\circ}, 20^{\prime}$ and northern latitude of $37^{\circ}, 05^{\prime}$ and $38^{\circ}, 05^{\prime}$ (Fig. 1) with approximately $4268 \mathrm{~km}^{2}$ in area and altitude in range of 1280 and 3608 above mean sea level. The Urmia Lake (UL) has a large storage capacity, regulating the inflow and outflow from a significant drainage area. The water depth varies from a few meters to near $130 \mathrm{~m}$ in northern and southern parts of aquifer, respectively. The groundwater flow direction is from west to east (UL). The major sources for recharging the Urmia Lake are four recurrent rivers, including Nazlou-chai, Rowzeh-chai, Shahrchai, and Barandouz-chai, which originate from the western mountains of the area. The mean input to the aquifer from these rivers and return flows from irrigated lands is about 290 million cubic meters (MCM) per year (Amiri et al., 2016a). In addition, infiltration from precipitation is near 37.7 MCM per year (Hamidi-razi et al., 2019). In this area, the irrigation is 
mainly from groundwater sources (Khatami Mashhadi, 2013). The oldest rock units of the PreCambrian are formed by meta volcanic series, acidic tuff, and diorite in the surrounding mountains of Urmia Lake, as well as metamorphous amphibolites and gneiss (Hamzehpour et al., 2018). Tertiary rocks in this plain are represented by limestone, conglomerate, sandstone, and shale (Hossein et al., 2018).

\section{[Fig. 1, here]}

\section{Geological conditions}

Azarshahr plain is located in Azerbaijan Province, northwest of Iran. The plain in UTM coordinates is in the longitudinal axis between 518,200- and 575,700-meters east and between 4,197,000- and 4,163,500-meters north. This area is in the west of East Azarbaijan Province and on the eastern shore of Urmia Lake, which is limited to the north of Tabriz plain and south of Azarshahr Travertine hills. The plain is bordered from the west by the Urmia Lake salty flat plains. Sahand volcanic altitudes are in the east of this plain, and the coasts and salt marsh of Lake Urmia have limited the western part of this plain (Jeihouni et al., 2018).

The Azarshahr plain is comprised of igneous, sedimentary, and volcanic rocks. While igneous rocks extend in the southeast of the Azarshahr plain, volcanic sedimentary rocks mainly cover the east of the area, particularly from northeast to southeastern (Fig. 1). Even though central and western parts of Azarshahr plain are covered by sedimentary rock consisting of quaternary sedimentary rock such as travertine and young traces, it is considered the main source of potable and agricultural groundwater supply (ATWA, 2009). The plain includes layers with ages of Jurassic to Quaternary which are under the strong domination of movements with Alpine origin. The Sahand alluvial tuff conformably overlies Pliocene marls, sandstones, and fish-bed layers. The southwestern part of study area includes Jurassic and Cretaceous limestone with 
Pliocene travertine, which is believed to be connected to the thermal mineral issuing from the Cretaceous limestone as well as from alluvial tuff. The alluvial water course and plain deposits of the study area are derived from the erosion of Sahand pyroclastic materials, which have transported by water and other agents in to the Azarshahr Plain.

The total area of Azarshahr is around $457 \mathrm{~km}^{2}$ while $124 \mathrm{~km}^{2}$ of that is covered by Azarshahr plain. The common border of the aquifer with UL is approximately $92 \mathrm{~km}$, which is the longest border with UL in compare to other aquifers in the region. However, this long mutual border and vicinity to UL makes the Azarshahr aquifer more vulnerable to the salty water invasion, which is more or less detectable in the samples taken from the outflow of the aquifer (Hossein et al., 2018). East and central parts of the Urmia region consist of wide plains where northern, western and southern partitions consist of mountainous regions (Alizadeh, 2013). Geologically, the study area consists of Sahand volcanic rocks from Late Miocene to Pleistocene from southeast of plain. Quaternary units consist of alluvial terraces with alluvial plain sediments. Quaternary travertines also have outcrops in the south and southwestern parts of the plain, which are of great interest in leveraging the groundwater quality.

As illustrated in Fig. 1, geological formations that are adjacent to or in the direction of groundwater movement, depending on the lithology of the formation and the physicochemical properties of the water, affect the groundwater quality (Daw et al., 2018). Also, because of tectonics in relation to hydrogen units and groundwater flow, it is necessary to study the lithology of the formations and tectonics of the area and their role in changing water quality and groundwater movement. In terms of topography, the highest elevation is the western slopes of Sahand Mountain and the lowest points around the Lake Urmia, which have an altitude of 3100 meters and 1282 meters above sea level, respectively (Gorgij and Moghaddam, 2016). 
Azarshahr plain only has a river called Gombrakhay River, which is also considered the main river. This river originates from the western slopes of Sahand Mountain and flows eastward to the west and after passing Azarshahr plain ends at Urumieh Lake. The existence of suitable agricultural land and flat plain has led to agricultural prevalence in this area and the main income of the majority of the villagers around Azarshahr is agricultural career. In the lower reaches of the hands it is dried, therefore, the groundwater is used for drinking, agriculture and sanitation in this area, but it is of great importance that increasing the harvesting of groundwater resources, in a rate higher than the recharge rate has led to exploitation of the aquifer. The maximum monthly mean precipitation falls in May $(53.96 \mathrm{~mm})$ and the minimum in August $(4.16 \mathrm{~mm})$ (Fatollahzadeh et al., 2016). Over the last few years, the average annual precipitation in the region has been significantly reduced. Therefore, it can be concluded that decreasing rainfall in recent years reduces feeding and increases hydraulic load loss in groundwater aquifers and can be effective in both degradation of water quality and infiltration of saline water. The climate of Azarshahr plain is under the influence of Mediterranean and cold weather streams (Delju et al., 2013; Motevalli et al., 2018).

\section{Sample collection and analysis}

To appropriately cover the study area, different sites in the plain were randomly selected for groundwater sampling and their respective location was recorded by a portable GIS device, (GRS-1, Skipper Technologies India Private Limited). Using Student's $t$-distribution, the number of samples within the $95 \%$ confidence level is determined as follows:

$$
n=(t s / e)^{2}
$$


where $t$ is the $t$-statistic value selected for a given confidence level (2.23 for confidence level of $95 \%), s$ is the overall standard deviation, and $e$ is the acceptable level of error or uncertainty. The degrees of freedom $(d f)$ which determines $t$ is first selected randomly and then modified by successive iterations. For $d f=10$ with $s=3.86$ and $e= \pm 1.5 \mu \mathrm{g} / \mathrm{g}$ uncertainty, a total number $(n)$ of 33 samples would be necessary.

Judgmental sampling strategy using prior knowledge of spatial and temporal variation of the pollutants was employed to identify the locations for sampling, particularly the location of the present pollutants (in our case around the outfall point). Moreover, a composite sampling method containing several separate samples taken at ten random time points has been employed. If the pollutant of interest was detected, then the individual samples have been analyzed individually and the average was recorded.

Sampling was carried out using a set of white polythene bottles. To maintain the sampling accuracy up to a level, the wells were pumped for $5 \mathrm{~min}$ and the sampling bottles were washed thoroughly with groundwater to be collected. To determine the suitability of groundwater for different uses such as agricultural, industrial and domestic uses, the data obtained from the sampling wells, monitored during June 2012 and June 2018 by the Ministry of Energy, which were analyzed for physiochemical parameters such as pH, TDS, EC, and hardness values (Table 1 and 2). The experimental values were compared with standard values recommended by World Health Organization (WHO, 2017) for drinking water and public health (Table 2). According to these results, in most parts of this basin, these values exceeded the prescribed limit of WHO. 


\section{[Tables 1 and 2, here]}

\section{Measured parameters and analytic procedure}

Parameters such as pH, EC, TDS (total dissolved solids), TH (total hardness), major cations $\left(\mathrm{Na}^{+}, \mathrm{K}^{+}, \mathrm{Ca}^{2+}\right.$, and $\left.\mathrm{Mg}^{2+}\right)$ and major anions $\left(\mathrm{CO}_{3}{ }^{2-}, \mathrm{HCO}_{3}{ }^{-}, \mathrm{SO}_{4}{ }^{2-}\right.$, and $\left.\mathrm{Cl}^{-}\right)$were taken into consideration. $\mathrm{pH}$ and $\mathrm{EC}$ of each sample were measured in situ by a digital $\mathrm{pH}$ and $\mathrm{EC}$ meter, respectively. TDS was determined gravimetrically at $105-110{ }^{\circ} \mathrm{C}$ (Kazi et al., 2009). In laboratory, the duplicate aqueous samples of $1000 \mathrm{~mL}$ of each batch collected were filtered through polycarbonate filter $(0.45 \mathrm{~mm}$ pore size $)$, and the samples were divided in two parts. One part was used for analysis of anions, while the second part treated with $2 \mathrm{~mL}$ of concentrated $\mathrm{HNO}_{3}$ solution was used for metal analysis.

The acid-treated water samples were analyzed for the determination of major cations by further 20-time dilution with ultra-pure water. $\mathrm{Ca}^{2+}, \mathrm{Na}^{+}$, and $\mathrm{K}^{+}$were measured by flame photometry (Model 410 Sherwood Incorporation, USA), while $\mathrm{Mg}^{2+}$ was determined by the flame atomic absorption spectrometer (FAAS), HACH Incorporation, USA. In case of anion concentrations, sulfate has been measured by $\mathrm{HACH}$ DR/2000 (direct reading spectrophotometer) using the method number 8051, chloride has been measured through argentometric course using the method number 2330 and bicarbonate has been measured by titration using the method number 4500, respectively (APHA, 1998).

\section{Statistical analysis}

The relationship between different dissolved species is used to reveal the origin of solutes as well as the main hydrogeochemical processes (such as dissolution, ion exchange, and enrichment or depletion of major ions) (Kumar et al., 2009). A Piper plot (proposed by Arthur 
M. Piper in 1944) and Gibbs diagram (introduced by R.J. Gibbs in 1970) were used to assess the hydrochemical facies of the analyzed waters and Mechanisms controlling the water chemistry (Tiwari et al., 2017; Baghvand et al., 2010). The water quality for irrigation was also assessed with Wilcox as an indicator of the suitability of water for agricultural use (Baghvand et al., 2010): $\% \mathrm{Na}^{+}$vs. EC (Wilcox diagram, proposed by L.V. Wilcox in 1955) and Sodium Adsorption Ratio (SAR) The ionic relations and the geochemical process were assessed with several diagrams: $\mathrm{Ca}^{2+}+\mathrm{Mg}^{2+}$ vs. $\mathrm{HCO}_{3}{ }^{-}+\mathrm{SO}_{4}{ }^{2-} ; \mathrm{Mg}^{2+} / \mathrm{Na}^{+}$vs. $\mathrm{Ca}^{2+} / \mathrm{Na}^{+} ; \mathrm{Na}^{+}$vs. $\mathrm{Cl}^{-}$. vs. $\mathrm{EC}$ (Riverside diagram) plots (Baghvand et al., 2010). GW Chart, Diagrams v. 6.52 and Microsoft Excel 2016 were used for this purpose.

\section{Principal components analysis}

Principal components analysis (PCA) is one of the best ordination methods that consist of an eigen analysis of a covariance or correlation matrix calculated on the original measurement data. Graphically, it can be described as a rotation of a swarm of data points in multidimensional space so that the longest axis (the axis with the greatest variance) is the first PCA axis, the second longest axis perpendicular to the first is the second PCA axis, and so forth. Assuming the sample parameters as the original set of variables, and the Euclidean distance matrix as an estimate of the correlation matrix explaining the correlations between each pair of samples, the PCA framework for grouping the samples into separate independent clusters was automatically assigned and formed. In the PCA method, the initial clusters are extracted out by the eigenvalueeigenvector analysis of the similarity matrix as presented in Eq. (1):

$\left(S-I \lambda_{i}\right) Y_{i}=0, \quad i=1,2, \ldots P$ 
where $S$ is a $P \times P$ Euclidean distance matrix, $I$ is the identity matrix, $\lambda_{i}$ are the characteristic roots (eigenvalues), and $Y_{i}$ are the corresponding eigenvectors. Eq. (3) is an eigenvalueeigenvector equation, $\lambda_{1} \geq \lambda_{2} \geq \ldots \geq \lambda_{p}$ are the real, nonnegative roots of the determinant polynomial of degree $P$ given as

$I\left(S-I \lambda_{i}\right) I=0$

For the values obtained from Eq. (2), $Y_{i}$ can be calculated. According to the PCA method, each of the $P$ independent principal components (factors) can be written as a linear combination of the original variables (water samples), with the elements of the $P$ eigenvectors as the coefficients of these linear combinations. There should be low similarities among samples that are associated with different clusters and high similarities among samples strongly associated with the same cluster.

\section{Hierarchical cluster analysis}

Nine variables $\left(\mathrm{Ca}^{2+}, \mathrm{Mg}^{2+}, \mathrm{Na}^{+}, \mathrm{K}^{+}, \mathrm{HCO}_{3}{ }^{-}, \mathrm{CO}_{3}^{2-}, \mathrm{Cl}-, \mathrm{SO}_{4}{ }^{2-}\right.$, and TDS $)$ and 33 water samples were considered for the cluster analysis. The Q-mode clustering analysis resulted in two major water groups (Groups A and B) and seven subgroups (SB), which were selected from the dendrogram or of the cluster analysis. Dissimilarity index of 0.25 was used to distinguish seven subgroups. The two major groups are distinguished by their TDS. Group-A waters have TDS less than $2000 \mathrm{mg} / \mathrm{L}$. Group-B waters have TDS greater than $2000 \mathrm{mg} / \mathrm{L}$. Group-A waters have three subgroups and Group-B waters have four subgroups. The samples clustered under each subgroup and the average values for each of the physicochemical composition are presented in Table 3. The average values for each of the composition of the subgroups produced by the HCA analysis reveal trends between them and they are the basis for the distinction of the subgroups. The HCA 
result is consistent with the analysis made on the basis of Piper plots. Most important trends are increase of $\mathrm{Na}$ and TDS towards the rift and the reverse in $\mathrm{Ca}$ and $\mathrm{Mg}$ as one goes down from SB-1 to SB-7. The relationship between the statistically defined clusters of samples and geographic location was prepared by plotting subgroup values for each sample. The seven subgroups are separated geographically, as well as physiographically with good correspondence between spatial locations and the HCA results. Samples that belong to the same subgroup are located in close proximity to one another suggesting more or less the same hydrogeochemical processes (evolution) and/or flow paths.

\section{[Table 3, here]}

\section{Results and discussion}

In this study, scree plot (introduced by Raymond B. Cattell in 1966) was used to select the number of the clusters. It can be observed from the scree plots (Fig. 2) for two periods that only two clusters are needed to group the water samples. These two groups contribute $85.62 \%$ in 2012 and $88.22 \%$ in 2018 , respectively. Therefore, it is clear that the water sample data for two seasons can be clustered into two groups.

\section{[Fig. 2, here]}

\section{pH}

According to WHO guidelines (WHO, 2017), the range of $\mathrm{pH}$ value prescribed for drinking purposes is $6.5-8.5$. The $\mathrm{pH}$ values of groundwater in the study area varied between 7.68 and 8.35 , indicating slightly acidic to slightly basic water. These $\mathrm{pH}$ values were all in the desirable ranges. According to $\mathrm{WHO}, \mathrm{pH}$ less than 6.5 or greater than 9.2 would markedly impair the potability of drinking water. $\mathrm{pH}$ usually has no direct impact on human health; 
however, higher value of $\mathrm{pH}$ can increase the scale formation in water pipes and also reduce disinfection potential of chloride (WHO, 2017). More alkaline water requires a longer contact time or a higher free residual chlorine level at the end of the contact time for adequate disinfection (WHO, 2017). For example, at $\mathrm{pH} 6.0-8.0$ the free residual chlorine must be $0.4-0.5$ $\mathrm{mg} / \mathrm{L}$, at $\mathrm{pH} 8.0-9.0$, it is rising to $0.6 \mathrm{mg} / \mathrm{L}$, chlorination become ineffective above $\mathrm{pH} 9.0$ (WHO, 2017).

\section{Electrical conductivity}

Electrical conductivity (EC) shows the concentration of ionized substances in water (WHO, 2017). The maximum permissible concentration of EC for drinking water is $1400 \mu \mathrm{s} / \mathrm{cm}$ (WHO, 2017). In this basin the EC values in the samples were in the range of 1553-12,300 $\mu \mathrm{s} / \mathrm{cm}$, indicating the higher EC values than that of prescribed limit for drinking water. The EC distribution is shown in Fig. 3a and 3b, which indicates high concentrations of total salts, especially in the east of this basin. Chebotarev (1955) studied on the chemical evolution of groundwater in the length of flow and stated that a bicarbonate-sulfate-chloride water type exists from recharge to discharge. In addition, the most important reason for EC increase in the Azarshahr aquifer most probably would be the salt water intrusion from the Urmia Lake (Amiri et al., 2014a).

[Fig. 3, here]

In general, according to Fig. $3 \mathrm{a}$ and $3 \mathrm{~b}$, it is possible to receive changes in the direction of increase in electrical conductivity in the Azarshahr plain from the eastern part and highlands to the western regions. In 2012, the lowest electrical conductivity in the southeast and northern part of the plain (stations No. 29 and No. 19) was reported to be 473 and $638 \mu \mathrm{S} / \mathrm{cm}$, respectively. 
However, in 2018, the lowest electrical conductivity was observed in the eastern and southeastern parts only at $567 \mu \mathrm{S} / \mathrm{cm}$. The northern parts of Azarshahr plain show more values of electrical conductivity than in 2012 .

As Fig. 3a and 3b indicate, the electrical conductivity in the northern and western parts of the plain is increasing. The process of increase is such that, for example, in well No. 4 , the electrical conductivity has reached $12,650 \mu \mathrm{S} / \mathrm{cm}$. Also, the increase in the central parts of the plain can be noticed. For example, at station No. 11, the electrical conductivity is reached to $10,340 \mu \mathrm{S} / \mathrm{cm}$ in 2018 . Considering the relatively high distance of these areas from Urmia Lake, it can be expected that, in addition to the effect of water penetration, the sharp increase in fossil fuels has a significant effect on salinity increase in the central parts of the plain. In general, by comparing the results, the amount of salts that can be increased from west to east in 2018 could be considered as one of the possible reasons for the influx of Urmia lake water into Azarshahr plain aquifer.

\section{Chloride}

The high concentrations of chloride can give a salty taste to drinking water (WHO, 2017). It can increase the rate of corrosion in water pipes (WHO, 2017). According to (WHO, 2017), the taste thresholds for chloride are in the range of $200-300 \mathrm{mg} / \mathrm{L}$. On the average, concentrations in excess of $250 \mathrm{mg} / \mathrm{L}$ can be detected by taste (WHO, 2017). The chloride concentration greater than $600 \mathrm{mg} / \mathrm{L}$ would substantially impair the potability of water. This value is the maximum permissible concentration for drinking water. In this study, the chloride values of groundwater were in the range of $161.5-3248.3 \mathrm{mg} / \mathrm{L}$, indicating high content of salty water. About $90 \%$ of water samples had higher chloride values than that of prescribed limit for 
drinking water. The chloride distribution is shown in Fig. 3c and 3d, which indicates a high concentration of total chloride.

According to Table 3, the pair(s) of variables with positive correlation coefficients and $p$ values below 0.050 tends to increase together. For the pairs with negative correlation coefficients and $p$ values below 0.050 , one variable tends to decrease while the other increases. For pairs with $p$ values greater than 0.050 , there is no significant relationship between the two variables. Fig. 4 shows a strong linear correlation between chloride and EC values for both study duration (2012 and 2018). The linear regression model between the groundwater electrical conductivity and the chloride concentrations proposed in this work for the 66 samples is very similar to the results by Abyaneh et al. (2005): $\left[\mathrm{Cl}^{-}\right]=9 \mathrm{EC}$ for $0.15<\mathrm{EC}<39.9 \mathrm{dS} / \mathrm{m}$. The relation in this work is $\left[\mathrm{Cl}^{-}\right]$ $=9.22 \mathrm{EC}$. On the other hand, the linear model $\left[\mathrm{Cl}^{-}\right]$, for the 66 samples corresponding to the area under study and collected in 2012, is also similar to the linear model proposed by Hajrasuliha et al. (1991): $\left[\mathrm{Cl}^{-}\right]=5.22 \mathrm{EC}$, for $\mathrm{EC}=16 \mathrm{dS} / \mathrm{m}$. The different models presented, where the water electrical conductivity was related to the chloride concentration, show good fit for the linear model, with $R$ fit values higher than 0.96. An approximation of the chloride concentration is possible with only the groundwater EC value.

\section{[Table 3, here] [Fig. 4, here]}

\section{Sulfate}

In 2012, the lowest and highest sulfate ions were reported in the northern part (station No. 19) and the central region (station No. 12) with the values of 0.15 and $20.8 \mathrm{mg} / \mathrm{L}$, respectively. However, in 2018, the least amount of sulfate ions in the eastern part (station No. 27) was equal to 1.2 and the largest amount was reported in the central section (station No. 10) equal to $14 \mathrm{mg} / \mathrm{L}$. Generally, according to Fig. 5, there are significant changes in the amount of 
sulfate ions in the central, southern, and western parts of the plain. Anion sulfate is the second most important anion in oceans and seawater, mainly found in magnesium sulfates, calcium, and potassium. The most important source of this ion in natural waters is metal sulfates such as iron, copper, nickel, lead, and zinc (Amiri et al., 2017). These sulfides are oxidized to sulfate due to atmospheric conditions and moisture, which will flow to groundwater through dissolved water (Baghvand et al., 2010).

According to Fig. 5a and 5b, it is obvious that the amount of sulfate ions in the southern, central, and western parts of the plain increases substantially. The increase trend is such that, for example, the sulfate ion at station No. 4 (located in the western part of the Gheshlagh region) is 9.89 in 2004 and $13.88 \mathrm{mg} / \mathrm{L}$ in 2012. Also, in the southern part of station No. 26 in Nadinlou, the amount of sulfate ions increased from $5.6 \mathrm{mg} / \mathrm{L}$ in 2012 to $13.8 \mathrm{mg} / \mathrm{L}$ in 2018 , respectively. The reason for this increase can be the excessive extraction of groundwater resources and the reduction of atmospheric precipitation. In other words, concentration of groundwater table is the most important reason for increasing salinity caused by sulfate.

\section{[Fig. 5, here]}

\section{Sodium}

Since sodium ion is often associated with ionic chloride due to its chemical properties, it is expected that in areas with a relatively high chloride ion, the sodium ion concentration would also be high. Accordingly, in areas where groundwater has low salinity and of relatively good quality, the concentration of sodium is similar to that of chloride and its amount gradually increases in direction of groundwater movement.

Generally, according to Fig. 5c and 5d, the trend of changes and increase of sodium ion in the Azarshahr plain can be easily correlated with changes in the ion chloride of the eastern 
regions to the western regions. In 2012, the lowest and highest sodium ion was reported in the southeast and western parts of the country (stations No. 29 located in Almussra and station No. 4 located at Gheshlagh) to be equal to 1.5 and $28.8 \mathrm{mg} / \mathrm{L}$, respectively. In 2018 , the lowest amount of sodium ion in the eastern part (station No. 27 in Malladuz) was 1.6 and the highest amount was reported at the same station No. 11 equal to $50 \mathrm{mg} / \mathrm{L}$. According to the results, a significant increase in sodium ion in all stations, especially in the central, southeast, and western parts of Azarshahr plain has been observed since 2012.

To study salinity changes, using the changes in sodium ion concentration in Azarshahr plain, Figs. 5c and 5d can also be used. According to the above figures, it is possible to receive sodium ion in the southeast and central parts of the country and to the north and west of the plain in this period. The growth trend is such that, for example, in station No. 4 in Gheshlagh (west of the study area) has risen from 28.8 in 2012 to $41 \mathrm{mg} / \mathrm{L}$ in 2018 . Also, the amount of sodium ion in the central and southern parts of Azarshahr plain can be considered in this period. For example, at stations No. 10 and No. 26 (respectively, in Dizaj Charagh and Nadinlou), the sodium ion in 2012 was changed from 3 to 8 and from 16 to $41 \mathrm{mg} / \mathrm{L}$ in 2018 , respectively. Generally, in all studied stations, the trend of increasing sodium ion is visible. Based on this, the reasons for higher concentration of sodium ion in this period can be considered as the reasons for higher Chloride concentration. In other words, the excessive increase in water extraction and the effect of saline water penetration on the coastal beds of Urmia Lake, especially in western areas, are due to the increase of salinity. 


\section{Total dissolved solids}

According to the results of the correlation analysis, there were correlations among the water quality parameters, which could reveal the possible sources of parameters or potential contributors of chemical components. Each pair of elements showed significant positive and negative correlations. A strong significant positive correlation was observed between EC and TDS and $\mathrm{Cl}^{-}(0.804-0.889 ; p<0.05)$, whereas TDS also demonstrated a strong significant positive correlation with $\mathrm{Cl}^{-}(0.998)$ for both periods of the study.

Fig. 6a represents the spatial distribution of bicarbonate in aquifer for both 2012 and 2018. During this time, the bicarbonate concentration decreased in central and southern part. The concentration of $\mathrm{HCO}_{3}{ }^{-}$in the water samples varied from 2.17 to $14.5 \mathrm{mg} / \mathrm{L}$ in 2012 and from 1.5 $\mathrm{mg} / \mathrm{L}$ to $15.5 \mathrm{mg} / \mathrm{L}$ in 2018 , respectively. According to WHO (2017), the maximum acceptable concentration of $\mathrm{HCO}_{3}{ }^{-}$in water for domestic purposes is $100 \mathrm{mg} / \mathrm{L}$. All the water samples have $\mathrm{HCO}_{3}{ }^{-}$values well within the permissible limit of WHO (2017). These results obtained are mainly attributed to the weathering-dissolution of carbonate minerals in the study area.

The spatial distributions of TDS are also shown in Fig. 6b and 6c, where red color denote high concentrations and blue color represents lower concentrations. The distributions of TDS and EC had significant positive correlations across the study area. The spatial distributions of calcium ion are shown in Fig. 6d and 6e for the two periods of the study. Table 3 represents the Correlation matrix of chemical constituents of groundwater of Azarshahr aquifer in June 2012 and 2018.

[Fig. 6, here] 


\section{Water quality for drinking purposes}

The percentages of each Schoeller classification for drinking consumption in June 2012 and 2018 are presented in Table 4. Fig. 7 represents the quality of the water samples from the groundwater during 2012 and 2018. Based on this information, it can be concluded that the quality of all water samples from the perspective of drinking consumption in 2018 was significantly lower than in 2012. As such, in 2018, samples of poor quality were also observed.

\section{[Fig. 7, here] [Table 4, here]}

\section{Quality and typology assessment of the groundwater}

Groundwater quality was determined using the Piper diagram which enables graphical representation of a lot of chemical analysis in one diagram. The cations are expressed as a percentage of the total cations in the left triangle and the anions are in the same right triangle. The diagram shows the chemical properties of the water in terms of the relative concentration of its constituents, not in terms of its absolute concentration, so that the type of water can be concluded quite easily.

Figs. 8 and 9 demonstrate the Piper and Durov diagrams of the groundwater samples in the study area, respectively. As shown in left triangle part, the concentration of $\mathrm{Ca}^{2+}$ is higher than the other cations, indicating the dominance of alkaline earths over alkali metals. However, In the right triangle, the concentration of $\mathrm{Cl}^{-}$is higher than that of $\mathrm{HCO}_{3}^{-}$, suggesting the dominance of strong acid over weak one, however, for some samples the concentration of $\mathrm{HCO}_{3}{ }^{-}$ is higher than that of $\mathrm{Cl}^{-}$and $\mathrm{SO}_{4}{ }^{2-}$, highlighting the abundance of the weak acid over strong one. High concentration of $\mathrm{Cl}^{-}$may be attributed to human activities (Wu et al., 2017), but in this study salt water intrusion has the strong potential to be a possible reason responsible for the high 
$\mathrm{Cl}^{-}$concentration. Most of the plots are situated in the central part of the right triangle, indicating no trace of anion dominancy.

\section{[Figs. 8 and 9, here]}

The hydrochemical types of groundwater suggest that the groundwater lies in the transition zone of the hydrogeological unit, and the important factors affecting it's chemistry are rock weathering, evaporation and human activities ( $\mathrm{Li}$ et al., 2016). The analyzed groundwater samples in the study area have been located near the top and left corner of the diamond part, showing temporary to permanent hardness based on (Nagaraju et al., 2016). The water type ranges from the $\mathrm{Ca}-\mathrm{Cl}$ type to mixed type (no cation-anion exceed $50 \%$ ) type according to Sadashivaiah et al. (2008). Basically, the groundwater of the area resembles a non-carbonated typology. In the nutrition zone of the aquifer, the water flow change to sulfate type, and finally, it is converted to the chlorine type due to evaporation. These areas consist of 13 stations from 33 sampling stations (No. 9-11, 18-20, 22, 24, 28, 30, 32, and 33), mainly located in the eastern and southeastern parts of the plain. The sulfate type is striped after the bicarbonate type and maintains the adjacency to the eastern heights (including stations No. 13 to 15 and No. 23). Possibly, the presence of gypsum compounds in these structures has caused sulfidation in these areas. The chlorine type consists of almost all western regions and parts of the central and southeast (stations No. 1 to $8,12,16,17,21,25,26$ and 31). It should be noted that in 2014, due to increased concentration of chloride ions, more areas and stations contain chlorine type water. 


\section{Water quality for irrigation purposes}

To evaluate suitability of groundwater for irrigation applications, TDS, EC, sodium adsorption ratio (SAR) were analyzed (Li et al., 2013). All determined groundwater concentrations used in these computations were in the unit of $\mathrm{mg} / \mathrm{L}$. The chemical quality of water is very important for agricultural use, and the quantity of agricultural products depends on the quality of water used in irrigation. From the agricultural perspective, the use of groundwater with high concentration of salts can cause soil salinity and increase the exchangeable sodium content. Particularly in arid and desert areas due to lack of rainfall and lack of proper soil leaching, this process is intensified. In the classification of irrigation water, in addition to determining the chemical properties of water, various factors such as soil gender, soil condition, irrigation water content, ambient temperature, chemical elements present in the soil and the type of cultivated plant should be studied.

One of the most common classifications of irrigation water is the classification based on the Wilcox diagram, presented by the US Department of Agriculture (Wilcox, 1955). The amount of sodium sucrose with calcium and magnesium can be estimated by the ratio of sodium absorption (SAR). The SAR value is calculated from the following equation:

$S A R=\frac{N a^{+}}{\sqrt{\frac{C a^{2+}+M g^{2+}}{2}}}$

In this classification, two chemical agents (SAR) and electrical conductivity (salinity risk) are considered, each of which is divided into four classes and generates a total of 16 different classes. C1S1 water is the best water for agriculture and C4S4 is the most unfavorable water for agriculture applications. In this form, increasing the amount of electrical conductivity, the effect of sodium becomes more severe. The various groups listed in the Wilcox classification 
are classified as follows (in this classification, $\mathrm{C}$ represents salinity and $\mathrm{S}$ represents the amount of sodium): (i) Very good waters with an EC of less than 250 micrometers per $\mathrm{cm}$ and placed in the C1S1 class; (ii) Good waters that belong to one of the C1S2, C2S1, or C2S2 classes; (iii) Moderate waters that belong to one of the $\mathrm{C} 1 \mathrm{~S} 3, \mathrm{C} 2 \mathrm{~S} 3, \mathrm{C} 3 \mathrm{~S} 1, \mathrm{C} 3 \mathrm{~S} 2$, and $\mathrm{C} 3 \mathrm{~S} 3$ classes and are suitable for irrigation of coarse texture and good drainage; and (iv) Inappropriate water, which is located in the C1S4, C2S4, C3S4, C4S4, C4S1, C4S2, and C4S3 classes, and the larger their coefficients, become inappropriate. For classification of groundwater in terms of agricultural uses during 2012 and 2018, the Wilcox diagram was used (Fig. 10).

\section{[Fig. 10, here]}

As shown in Fig. 10, many samples are placed in the C3S1, C4S1, and C4S2 classes for both periods. The number of very few samples in the $\mathrm{C} 2 \mathrm{~S} 1$ class, or the very good category, has been used for agriculture purposes. The percentage of each Wilcox classification for agricultural consumption in Azarshahr plain is given in Table 5. Based on the above tables, it can be concluded that, as time passes, the percentage of samples in the good class of C2S1 has been reduced, which could also be a further indicator of increasing salinity in the aquifer. Also, in Tables 6 and 7, the classification of each sampling station for June 2012 and 2018 from the perspective of agricultural application is presented, respectively.

\section{[Tables 5, 6, and 7, here]}

\section{$\mathrm{EC}$ vs $\mathrm{Cl}^{-} / \mathrm{Cl}^{-}+\mathrm{HCO}_{3}^{-}$molar ratio}

There is less evidence that the anthropogenic activities significantly would influence solute concentrations in the aquifer since according to Fig. 11, most water samples fell within the Gibbs diagram (Kou et al., 2019). Rather, most hydrochemical parameters fell within the fields 
defined by $\mathrm{Na}^{+} /\left(\mathrm{Na}^{+}+\mathrm{Ca}^{2+}\right)$ or $\mathrm{Cl}^{-} /\left(\mathrm{Cl}^{-}+\mathrm{HCO}_{3}{ }^{-}\right)$end members, which suggests that the aquifer chemistry is predominantly affected by rock weathering (Madhav et al., 2018).

\section{[Fig. 11, here]}

\section{$\mathrm{Na}^{+} / \mathrm{Cl}^{-}$versus $\mathrm{Cl}^{-}$and salinization sources}

The relationship between $\mathrm{Na}^{+} / \mathrm{Cl}^{-}$molar ration versus $\mathrm{Cl}^{-}$is helpful in identifying the salinization sources in Aquifers. If the ration is approximately equal to unity then most probably the source of these ions is halite dissolution (Kumar et al., 2009). If the ratio is greater than the unity, it is typically interpreted as Na released from a silicate weathering reaction. A ratio less than unity indicates that the addition of $\mathrm{Cl}^{-}$, is due to water level rise which causes more salt dissolution from the soil or mixing of wastewater with ground water. As shown in Fig. 12a, while a portion of the wells fall below one in $\mathrm{Na}^{+} / \mathrm{Cl}^{-}$ratio, another portion of them fall over one $\mathrm{Na}^{+} / \mathrm{Cl}^{-}$ratio making it hard to clearly understand the source of the salinization. In comparison with these countries, Iran is less severely affected by groundwater salinity pollution (Table 8).

[Fig. 12, here] [Table 8, here]

\section{Degree of salinization}

The relationship between $\mathrm{HCO}_{3}{ }^{-} / \mathrm{Cl}^{-}$ratio with $\mathrm{Cl}^{-}$for the majority of wells (as a whole), exhibited a pronounced negative slope indicating the reverse relationship between carbonate (represents freshening) and $\mathrm{Cl}^{-}$(represents salinization) (Fig. 12b). Based on the inverse of Simpson's ratio, the influence of saline water can be classified into six classes. In general, a $\mathrm{HCO}_{3}{ }^{-} / \mathrm{Cl}^{-}$ratio $\mathrm{N}_{2}$ indicates freshwater recharge whereas a ratio less than unity indicates higher degrees (or potential) of salinization (Chaudhuri and Srinivasulu, 2014; October et al., 2013). 


\section{$\mathrm{Mg}^{2+} / \mathrm{Ca}^{2+}$ versus $\mathrm{Cl}^{-}$and salinization sources}

In groundwater, $\mathrm{Mg}^{2+} / \mathrm{Ca}^{2+}$ ratio is usually less than unity while in sea water the $\mathrm{Mg}^{2+} / \mathrm{Ca}^{2+}$ ratio greater than one. Thus, higher ratios of $\mathrm{Mg}^{2+} / \mathrm{Ca}^{2+}$ can be found in seawater intrusion zones and similarly in areas experiencing of dolomite dissolution. It should be noted that $81.3 \%$ of the wells exhibit $\mathrm{Mg}^{2+} / \mathrm{Ca}^{2+}$ ratios $\mathrm{N} 1$, indicating that seawater intrusion, saltwater up-coning, reverse cation exchange, dolomite dissolution processes or sewage invasion may play a significant role on the groundwater chemistry signatures in the study area. Based on a study by Mayo and Loucks (1995), a distinction between the areas of calcite and dolomite dissolution can be identified by calculating the $\mathrm{Mg}^{2+} / \mathrm{Ca}^{2+}$ molar ratios of these cations. If the molar ratio is less than one, the dissolution of calcite has greater contribution to the water chemistry, whereas greater prevalence of dolomite dissolution occurs, when the $\mathrm{Mg}^{2+} / \mathrm{Ca}^{2+}$ molar ratio is equal or N1. Katz et al. (1997) describe that lower molar ratios (i.e. less than 0.5) indicate silicate weathering sources and/or processes are occurring. As shown in Fig. 13, only one well exhibited $\mathrm{Mg}^{2+} / \mathrm{Ca}^{2+}$ a ratio lower than 0.5 , which reveal that negligible silicate-weathering processes were occurring in the study area. The average of $\mathrm{Mg}^{2+} / \mathrm{Ca}^{2+}$ molar ratio for wells within all clusters are $\mathrm{N} 1$, with the exception of cluster 6 . This result reveals that calcite dissolution is occurring (and predominant) in cluster 6 (under the direct impact of rainfall), while the other clusters are impacted by seawater and saltwater intrusion (i.e. clusters 3 and 5) or influenced by dolomite dissolution (i.e. clusters 1, 2, 4, and 7). It can be concluded that dolomite dissolution is the predominant hydrogeochemical process in comparing with calcite dissolution in the study area. Relative to the wells of cluster 5 which located close to the shoreline, the wells of cluster 3 shows lower $\mathrm{Mg}^{2+} / \mathrm{Ca}^{2+}$ molar ratio and lower $\mathrm{Cl}^{-}$concentration. This is a chemical signature that can be used to distinguish between seawater intrusion area and saltwater up-coning area. Meanwhile, 
the higher $\mathrm{Mg}^{2+} / \mathrm{Ca}^{2+}$ ratio and lower $\mathrm{Cl}^{-}$concentration are characterized the wells of cluster 2 in the NE part of the study area when comparing them with the wells of cluster 1 in the SE part. The higher $\mathrm{Mg}^{2+}$ concentration in the north can be attributed to the dissolution of carbonate matrix of sandstone which is rich in $\mathrm{Mg}^{2+}$ (Gavish and Friedman, 1969). This dissolution is a result of acidic medium of the nitrate pollution which is higher in the eastern side of the northern area. Moreover, among the seven clusters, the $\mathrm{Mg}^{2+} / \mathrm{Ca}^{2+}$ ratio is recorded for the wells of cluster 2 then for clusters 1 and 5 . This is a clear indication that the eastern clusters 1 and 2 were influenced by Eocene brackish water which is characterized by $\mathrm{Na}-\mathrm{Mg}-\mathrm{Cl}$ water type (Vengosh et al., 2005).

\section{[Fig. 13, here]}

Fig. 14 shows the annual precipitation and salinity changes between 2012 and 2018. The mean precipitation value was about $461 \mathrm{~mm}$ in the study period. The maximum and minimum annual precipitations were estimated about $445 \mathrm{~mm}$ and $145 \mathrm{~mm}$ in 2012 and 2018, respectively. The mean salinity was approximated to be $41 \mathrm{ppm}$ in the study area. While the maximum salinity was recorded in December 2017 with the value of $88 \mathrm{ppm}$, the minimum salinity occurred in September 2013 with the respective value of $8.4 \mathrm{~mm}$. According to Fig. 14, the salinity showed a steady trend from July 2012 to January 2014, however, starting from February 2014 the trend showed a dramatic escalation by $400 \%$ and reached the highest value of $88 \mathrm{ppm}$ in December 2017, then the trend fluctuated around this value till July 2018 at which the salinity was recorded to be $87 \mathrm{ppm}$. The dashed lines in Fig. 14 show the average precipitation and salinity in the study area between 2012 and 2018 .

[Fig. 14, here] 
The measured parameters throughout the sampling wells have been statistically monitored and their respective behavior analyzed using clustering technique. The detailed information about the analysis is summarized on Tables 9-14. Squared Euclidean distance as linkage method was employed for variables $\mathrm{pH}, \mathrm{EC}$, TDS, major cations $\left(\mathrm{Na}^{+}, \mathrm{K}^{+}, \mathrm{Ca}^{2+}\right.$, and $\left.\mathrm{Mg}^{2+}\right)$ and major anions $\left(\mathrm{CO}_{3}{ }^{2-}, \mathrm{HCO}_{3}{ }^{-}, \mathrm{SO}_{4}{ }^{2-}\right.$, and $\left.\mathrm{Cl}^{-}\right)$. According to the dendrogram resulted from clustering analysis (Fig. 15a), two different groups were distinguished among sampling wells, one for EC values lower than $2000 \mathrm{mS} / \mathrm{cm}$ and another one for $\mathrm{EC}$ values bigger than $2000 \mathrm{mS} / \mathrm{cm}$. Considering the location of different stations, it is seen that the stations grouped in cluster $\mathrm{A}(1,2,7,10,11,13,14,15,16,18,19,20,21,22,23,24,25,26,27,28,29,30,31,32$, and 33) are mainly located in central and eastern parts of the study area, while the ones grouped in cluster B $(3,4,5,6,8,9,12$, and 17) are contributed to western boundaries respectively. The categorization pattern of the Dendrogram in June 2012 is in line with the spatial distribution of analyzed parameters. In other words, the value of the considered variables in stations grouped in cluster B (western parts) are higher in comparison with that of stations grouped in cluster A (central and Eastern parts of the study area). Accordingly, it may be concluded that the stations located alongside the western boundaries (adjacent to Urmia Lake) of the study area show the highest salinity hazard in groundwater quality. Similarly, the categorization of the dendrogram in June 2018 is in line with the spatial distribution of analyzed parameters, nevertheless, the salinity hazard was detected in several Eastern wells (cluster A: 4, 6, 8, and 9) of the study area.

\section{[Fig. 15, here] [Tables 9-14, here]}

\section{Conclusions}

An assessment over the quality and hydrochemistry of an aquifer adjacent to a hypersaline lake has been presented. The north-west of Iran is the host for the largest hypersaline lake in 
Western Asia, namely Urmia Lake. The results significantly highlighted the formulated hypothesis that the groundwater is suitable for irrigation and drinking applications as well as the physico-chemical analysis of groundwater samples revealed that the majority of water samples during 2012 were found to be within acceptable limits as prescribed by WHO. However, as per total hardness classification, groundwater samples of the majority $(>90 \%)$ of the sites fall in the category of absolutely hard water ranging from moderately hard to very hard. The results for chemical analysis of groundwater samples represented that the mean concentration for ionic dominance pattern is in the order of $\mathrm{Ca}^{2+}>\mathrm{Na}^{+}>\mathrm{Mg}^{2+}>\mathrm{K}^{+}$for cations and $\mathrm{HCO}_{3}{ }^{-}>\mathrm{SO}_{4}{ }^{2-}>$ $\mathrm{Cl}^{-}$for anions during 2012, whereas the respective pattern for 2018 is calcium $>\mathrm{Mg}^{2+}>\mathrm{Na}^{+}>$ $\mathrm{K}^{+}$for cations and $\mathrm{Cl}^{-}>\mathrm{HCO}_{3}{ }^{-}>\mathrm{SO}_{4}{ }^{2-}$ for anions. Based on obtained values of $\mathrm{EC}, \mathrm{SAR}, \mathrm{Na} \%$, and the salinity diagram, it can be concluded that most of the sampling points in the study area are appropriate for irrigation purposes both in 2012 and 2018. According to the hydrochemical and statistical evaluations, the following points can be drawn:

(1) The influence of saline water on Azarshahr plain, especially in western parts, is clearly visible. As can be seen in almost all stations in the western part (Qeshlagh region), a significant increase in electrical conductivity is observed.

(2) The thinner western areas of the plain compared to the eastern areas can increase groundwater retention in these areas and ultimately lead to increased solute dissolution and increased salinity.

(3) Clustering analysis revealed the salinity hazard for the western stations in June 2012, nevertheless, in June 2018, more vulnerable stations were detected in central and eastern parts of the study area. 
Despite these promising results, it is recommended that some future research would be required to provide new insights in this area. Especially, in terms of new methods for aquifer vulnerability assessment, the use of methods such as Susceptibility Index-Contamination Degree (SICODE), soil contamination degree index (CD), combination of DRASTIC, Goldberg, PI, and Susceptibility Index with hydrological and meteorological data will provide deeper understanding of the leveraging parameters in aquifer and groundwater sustainability practices. Although this study was conducted based on a comprehensive data gathered in the field, it took into consideration the most important elements active in aquifers which are limited to several compounds. In this regard, focusing on the more active elements and considering them in the analysis of water quality judgments shall be an interesting idea for upcoming future research on this topic. Some of the potential elements for consideration would be heavy metals, radioactive, and rare earth elements.

\section{Conflict of interest statement}

There is no conflict of interest declared by the authors.

\section{References}

Alizadeh, A. (2013). Active Faults on the Satellite Image of Azerbaijan Province, Northwestern Iran. Geoinformatics \& Geostatistics: An Overview, 01(03), 1-4. https://doi.org/10.4172/2327-4581.1000110

Almeida, L. De, Enoch, J., Werneck, F., \& Llacer, H. (2018). Environmental factors and groundwater behavior in an agricultural experimental basin of the Brazilian central plateau. Applied Geography, 94, 272-281. https://doi.org/10.1016/j.apgeog.2018.02.007 
Amiri, V., Nakhaei, M., \& Lak, R. (2017). Using radon-222 and radium-226 isotopes to deduce the functioning of a coastal aquifer adjacent to a hypersaline lake in NW Iran. Journal of Asian Earth Sciences. https://doi.org/10.1016/j.jseaes.2017.07.015

Amiri, V., Nakhaei, M., Lak, R., \& Kholghi, M. (2016a). Assessment of seasonal groundwater quality and potential saltwater intrusion: a study case in Urmia coastal aquifer (NW Iran) using the groundwater quality index (GQI) and hydrochemical facies evolution diagram (HFE-D). Stochastic Environmental Research and Risk Assessment, 30(5), 1473-1484. https://doi.org/10.1007/s00477-015-1108-3

Amiri, V., Nakhaei, M., Lak, R., \& Kholghi, M. (2016b). Geophysical, isotopic, and hydrogeochemical tools to identify potential impacts on coastal groundwater resources from Urmia hypersaline Lake, NW Iran. Environmental Science and Pollution Research, https://doi.org/10.1007/s11356-016-6859-y

Amiri, V., Rezaei, M., \& Sohrabi, N. (2014). Groundwater quality assessment using entropy weighted water quality index (EWQI) in Lenjanat, Iran. Environmental Earth Sciences, 72(9), 3479-3490. https://doi.org/10.1007/s12665-014-3255-0

APHA, Greenberg, A. E., Taras, M. J., Hoak, R. D., American Public Health Association American Water Works Association \& Water Pollution Control Federation (APHAAWWA-WPCF), (1998). Standard methods for the examination of water and wastewater/prepared and published jointly by the American Public Health Association, American Water Works Association, Water Pollution Control Federation; joint editorial board, Michael J. Taras, Arnold. xxxv, 874 p. : https://doi.org/ISBN 9780875532356

Arabameri, A., Rezaei, K., Cerda, A., Lombardo, L., Rodrigo-comino, J. (2019). Science of the Total Environment GIS-based groundwater potential mapping in Shahroud plain, Iran . A 
comparison among statistical (bivariate and multivariate), data mining and MCDM approaches. Science of the Total Environment, 658, 160-177. https://doi.org/10.1016/j.scitotenv.2018.12.115

Argamasilla, M., Barberá, J. A., Andreo, B. (2017). Science of the Total Environment Factors controlling groundwater salinization and hydrogeochemical processes in coastal aquifers from southern Spain. Science of the Total Environment, 580, 50-68. https://doi.org/10.1016/j.scitotenv.2016.11.173

Azerbaijan Territorial Water Association (ATWA) (2009). Detailed data collection from discharges of pumping wells and Qanats in the Azarshahr plain, Report in Persian.

Baghvand, A., Nasrabadi, T., Bidhendi, G. N., Vosoogh, A., Karbassi, A., Mehrdadi, N. (2010). Groundwater quality degradation of an aquifer in Iran central desert. Desalination, 260(1-3), 264-275. https://doi.org/10.1016/j.desal.2010.02.038

Bertrand, A., Nathalie, D., Cédric, D., Frédéric, G. (2006). Hydro-socio-economic implications for water management strategies: the case of Roussillon coastal aquifer. Retrieved from https://hal.archives-ouvertes.fr/hal-00468031

Chebotarev, I. I. (1955). Metamorphism of natural waters in the crust of weathering-3. Geochimica et Cosmochimica Acta, 8(4), 198-212. https://doi.org/10.1016/00167037(55)90053-3

Daw, M. M., Ali, E. R., Toriman, M. E. (2018). Nitrate contamination in groundwater agricultural of Samno and Elzegan area, Fazan region, Libya. International Journal of Engineering \& Technology, 7(2.29), 56-59.

Delju, A. H., Ceylan, A., Piguet, E., Rebetez, M. (2013). Observed climate variability and change in Urmia Lake Basin, Iran. Theoretical and Applied Climatology, 111(1-2), 285- 
296. https://doi.org/10.1007/s00704-012-0651-9

Fatollahzadeh, M., Khanmohammadi, M., Bazmani, A., Mirsamadi, N., Jafari, R., Mohebali, M., Fallah, E. (2016). Survey of feline visceral leishmaniasis in Azarshahr area, north west of Iran, 2013. Journal of Parasitic Diseases, 40(3), 683-687. https://doi.org/10.1007/s12639-014-0559-7

Ferrer, N., Folch, A., Lane, M., Olago, D., Odida, J., Custodio, E. (2019). Groundwater hydrodynamics of an Eastern Africa coastal aquifer, in- cluding La Niña 2016 - 17 drought. Science of the Total Environment, 661, 575-597. https://doi.org/10.1016/j.scitotenv.2019.01.198

Gallardo, A. H., Reyes-Borja, W., Tase, N. (2005). Flow and patterns of nitrate pollution in groundwater: A case study of an agricultural area in Tsukuba City, Japan. Environmental Geology, 48(7), 908-919. https://doi.org/10.1007/s00254-005-0029-8

Gerten, D., Hoff, H., Rockström, J., Jägermeyr, J., Kummu, M., Pastor, A. V. (2013). Towards a revised planetary boundary for consumptive freshwater use: Role of environmental flow requirements. Current Opinion in Environmental Sustainability, 5(6), 551-558. https://doi.org/10.1016/j.cosust.2013.11.001

Gorgij, A. D., Moghaddam, A. A. (2016). Vulnerability Assessment of saltwater intrusion using simplified GAPDIT method: a case study of Azarshahr Plain Aquifer, East Azerbaijan, Iran. Arabian Journal of Geosciences, 9(2), 1-13. https://doi.org/10.1007/s12517-015$2200-1$

Gorgij, A. D., Wu, J., Moghadam, A. A. (2019). Groundwater quality ranking using the improved entropy TOPSIS method: a case study in Azarshahr plain aquifer, east Azerbaijan, Iran. Human and Ecological Risk Assessment: An International Journal, 
25(1-2), 176-190. https://doi.org/10.1080/10807039.2018.1564235

Haidu, I., Nistor, M. (2019). Groundwater vulnerability assessment in the Grand Est region, France. Quaternary International, (April 2018), 1-15. https://doi.org/10.1016/j.quaint.2019.07.024

Hajrasuliha, S., Cassel, D. K., Rezainejad, Y. (1991). Estimation of chloride ion concentration in saline soils from measurement of electical conductivity of saturated soil extracts. Geoderma 49, 117-127

Hamidi-razi, H., Mazaheri, M., Carvajalino-fernández, M., Vali-samani, J. (2019). Investigating the restoration of Lake Urmia using a numerical modelling approach. Journal of Great Lakes Research, 45(1), 87-97. https://doi.org/10.1016/j.jglr.2018.10.002

Hamzehpour, N., Karimian, M., Mola, S., Abasiyan, A., Dill, H. G. (2018). Catena Pedogenic evidence of Urmia Lake's maximum expansion in the late Quaternary. Catena, 171(February), 398-415. https://doi.org/10.1016/j.catena.2018.07.019

Hossein, A., Khaghani, A., Macdonald, A. B., Nguyen, P., Karimi, N. (2018). Science of the Total Environment The Lake Urmia environmental disaster in Iran: A look at aerosol pollution. Science of the Total Environment, 633, 42-49. https://doi.org/10.1016/j.scitotenv.2018.03.148

Hu, K. X., Awange, J. L., Kuhn, M., Saleem, A. (2019). Spatio-temporal groundwater variations associated with climatic and anthropogenic impacts in South-West Western Australia. $\begin{array}{lllll}\text { Science of The Total Environment, } & 696, & 133599 .\end{array}$ https://doi.org/10.1016/j.scitotenv.2019.133599

Jeihouni, M., Toomanian, A., Kazem, S., Hamzeh, S., Pilesjö, P. (2018). Journal of African Earth Sciences Long term groundwater balance and water quality monitoring in the 
eastern plains of Urmia Lake, Iran: A novel GIS based low cost approach. Journal of African Earth $\quad$ Sciences, $\quad 147$ (June), $11-19$. https://doi.org/10.1016/j.jafrearsci.2018.06.017

Kazi, T. G., Arain, M. B., Jamali, M. K., Jalbani, N., Afridi, H. I., Sarfraz, R. A., Baig, J. A., Shah, A. Q. (2009). Assessment of water quality of polluted lake using multivariate statistical techniques: A case study. Ecotoxicology and Environmental Safety, 72(2), 301309. https://doi.org/10.1016/j.ecoenv.2008.02.024

Khatami Mashhadi, S. (2013). Nonlinear chaotic and trend analyses of water level at Urmia Lake, Iran. TVVR13/5012.

Kumar, M., Kumari, K., Singh, U. K., Ramanathan, A. L. (2009). Hydrogeochemical processes in the groundwater environment of Muktsar, Punjab: conventional graphical and multivariate statistical approach. Environmental Geology, 57(4), 873-884.

Li, P. (2016). Major Ion Chemistry and Quality Assessment of Groundwater in and Around a Mountainous Tourist Town of China. Exposure and Health, (126). https://doi.org/10.1007/s12403-016-0198-6

Li, P., Wu, J., Qian, H. (2013). Assessment of groundwater quality for irrigation purposes and identification of hydrogeochemical evolution mechanisms in Pengyang County, China. Environmental Earth Sciences, 69(7), 2211-2225. https://doi.org/10.1007/s12665-0122049-5

Malov, A. I., Tokarev, I.V. (2019). Using stable isotopes to characterize the conditions of groundwater formation on the eastern slope of the Baltic Shield (NW Russia). Journal of Hydrology, 578(July), 124130. https://doi.org/10.1016/j.jhydrol.2019.124130

Mayo, A.L., Loucks, M.D. (1995). Solute and isotopic geochemistry and ground water flow in 
the central Wasatch Range, Utah. Journal of Hydrology, 172, 31-59.

Mehrdadi, N., Ghobadi, M., Nasrabadi, T., \& Hoveidi, H. (2006). Evaluation of the quality and self purification potential of Tajan River using Qual2e model. Journal of Environmental Health Science \& Engineering, 3(3), 199-204.

Melaku, N. D., Wang, J. (2019). A modified SWAT module for estimating groundwater table at Lethbridge. Journal of Hydrology, 575, 420-431. https://doi.org/10.1016/j.jhydrol.2019.05.052

Moreau, M., Hadfield, J., Hughey, J., Sanders, F., Lapworth, D. J., White, D., \& Civil, W. (2019). A baseline assessment of emerging organic contaminants in New Zealand groundwater. Science of the Total Environment, 686, 425-439. https://doi.org/10.1016/j.scitotenv.2019.05.210

Motevalli, A., Moradi, H. R., Javadi, S. (2018). A Comprehensive evaluation of groundwater vulnerability to saltwater up-coning and sea water intrusion in a coastal aquifer (case study: Ghaemshahr-juybar aquifer). Journal of Hydrology, 557, 753-773. https://doi.org/10.1016/j.jhydrol.2017.12.047

Nagaraju, A., Muralidhar, P., Sreedhar, Y. (2016). Hydrogeochemistry and Groundwater Quality Assessment of Rapur Area, Andhra. (April), 88-99.

Nasrabadi, T., Bidabadi, N. S. (2013). Evaluating the spatial distribution of quantitative risk and hazard level of arsenic exposure in groundwater, case study of Qorveh County, Kurdistan Iran. Iranian Journal of Environmental Health Science and Engineering, 10(30), 1-8. https://doi.org/10.1186/1735-2746-10-30

Pei-Yue, L., Hui, Q., \& Jian-Hua, W. U. (2010). Groundwater quality assessment based on improved water quality index in Pengyang County, Ningxia, Northwest China. E-Journal 
of Chemistry, 7, 209-217.

Petersen, L., Heynen, M., Pellicciotti, F. (2017). Freshwater Resources: Past, Present, Future. International Encyclopedia of Geography: People, the Earth, Environment and Technology, 1-11. https://doi.org/10.1002/9781118786352.wbieg0712

Ponsadailakshmi, S., Sankari, S. G., Prasanna, S. M., Madhurambal, G. (2018). Evaluation of water quality suitability for drinking using drinking water quality index in Nagapattinam district, Tamil Nadu in Southern India. Groundwater for Sustainable Development, 6 (September 2016), 43-49. https://doi.org/10.1016/j.gsd.2017.10.005

Reza, R., Singh, G. (2010). Assessment of Ground Water Quality Status by Using Water Quality Index Method in Orissa, India. World Applied Sciences Journal, 9(12), 1392-1397.

Rowshan, G. R., Mohammadi, H., Nasrabadi, T., Hoveidi, H., Baghvand, A. (2007). The role of climate study in analyzing flood forming potential of water basins. International Journal of Environmental Research, 1(3), 231-236. https://doi.org/10.1093/qjmed/hcs152

Sadashivaiah, C., Ramakrishnaiah, C. R., Ranganna, G. (2008). Hydrochemical analysis and evaluation of groundwater quality in Tumkur Taluk, Karnataka State, India. International Journal of Environmental Research and Public Health, 5(3), 158-164.

Selvam, S., Manimaran, G., Sivasubramanian, P., Balasubramanian, N., \& Seshunarayana, T. (2014). GIS-based evaluation of water quality index of groundwater resources around Tuticorin coastal city, South India. Environmental Earth Sciences, 71(6), 2847-2867. https://doi.org/10.1007/s12665-013-2662-y

Shah, M. C., Shilpkar, P. G., Acharya, P. B. (2008). Ground water quality of Gandhinagar Taluka, Gujarat, India. E-Journal of Chemistry, 5(3), 435-446. https://doi.org/10.1155/2008/481694 
Thirumalini, S., Joseph, K. (2009). Correlation between electrical conductivity and total dissolved solids in natural waters. Malaysian Journal of Science, 28(1), 55-61. https://doi.org/10.22452/mjs.vol28no1.7

Tiwari, K., Goyal, R., \& Sarkar, A. (2017). GIS-based spatial distribution of groundwater quality and regional suitability evaluation for drinking water. Environmental Processes, 4(3), 645-662. https://doi.org/10.1007/s40710-017-0257-4

Vižintin, G., Ravbar, N., Janež, J., Koren, E., Janež, N., Zini, L., Treu, F., Petrič, M. (2018). Integration of models of various types of aquifers for water quality management in the transboundary area of the Soča/Isonzo river basin (Slovenia/Italy). Science of the Total Environment, 619-620, 1214-1225. https://doi.org/10.1016/j.scitotenv.2017.11.017

WHO (2017). World Health Organization, Guidelines for drinking-water quality: fourth edition incorporating the first addendum, Licence: CC BY-NC-SA 3.0 IGO, Geneva, Switzerland.

Wilcox, L. V. (1955). Classification and use of irrigation water. Agricultural Circular No. 969,Washington, DC: USDA., (969), 1-19. https://doi.org/USDA Circular No. 969.

Wu, J., Wang, L., Wang, S., Tian, R., Xue, C. (2017). Spatiotemporal variation of groundwater quality in an arid area experiencing long-term paper wastewater irrigation, northwest. Environmental Earth Sciences, 76(13), 1-14. https://doi.org/10.1007/s12665-017-6787-2 


\section{FIGURE CAPTIONS}

Fig. 1. Location and geological map of the study area (Azarshahr aquifer)

Fig. 2. Scree plot for data of June 2012 and June 2018

Fig. 3. Spatial distributions of EC in (a) June 2012 and (b) June 2018; and chloride in (c) June 2012 and (d) June 2018

Fig. 4. (a) Correlation of chloride with EC value in June 2012 and 2018 (b) $\mathrm{Na}^{+} / \mathrm{Cl}^{-}$(mass) versus EC $(\mu \mathrm{S} / \mathrm{cm})$

Fig. 5. Spatial distributions of sulfate in (a) June 2012 and (b) June 2018; and sodium in (c) June 2012 and (d) June 2018

Fig. 6. Spatial distributions of bicarbonate in (a) June 2012 and (b) June 2018; TDS in (c) June 2012 and (d) June 2018; and calcium in (e) June 2012 and (f) June 2018

Fig. 7. Water quality for drinking based on Schuller classification (a) June 2012 and (b) June 2018

Fig. 8. Piper diagram of major ions in groundwater of the two periods in (a) June 2012 and (b) June 2018

Fig. 9. Durov diagrams of the samples for the June 2012 (up) and June 2018 (down)

Fig. 10. Wilcox diagram for groundwater of the study area (a) June 2012 (b) June 2018

Fig. 11. Gibbs plots for chemistry of groundwater samples (a) sodium, chloride, and TDS; and (b) chloride, bicarbonate, and TDS

Fig. 12. (a) $\mathrm{Na}^{+} / \mathrm{Cl}^{-}$ratio versus $\mathrm{Cl}^{-}$relationship for the samples in June 2012 and 2018; and (b) scatter plot of $\mathrm{HCO}_{3}{ }^{-} / \mathrm{Cl}^{-}$molar ratio versus $\mathrm{Cl}^{-}$for 33 samples in June 2012 and June 2018

Fig. 13. (a) Scatter plot of $\mathrm{Mg}^{2+} / \mathrm{Ca}^{2+}$ molar ratio versus $\mathrm{Cl}^{-}$for 33 samples in June 2012 and Jun 2018; and (b) characteristic ionic relationships $\left(\mathrm{Mg}^{+2}\right.$ vs. $\left.\mathrm{Ca}^{+2}\right)$

Fig. 14. Salinity and precipitation time series for the period between June 2012 and June 2018

Fig. 15. Dendrogram resulting from cluster analysis using squared Euclidean distance and centroid agglomerative method on the sub-composition of sampling wells (a) June 2012 and (b) June 2018 


\section{FIGURES}

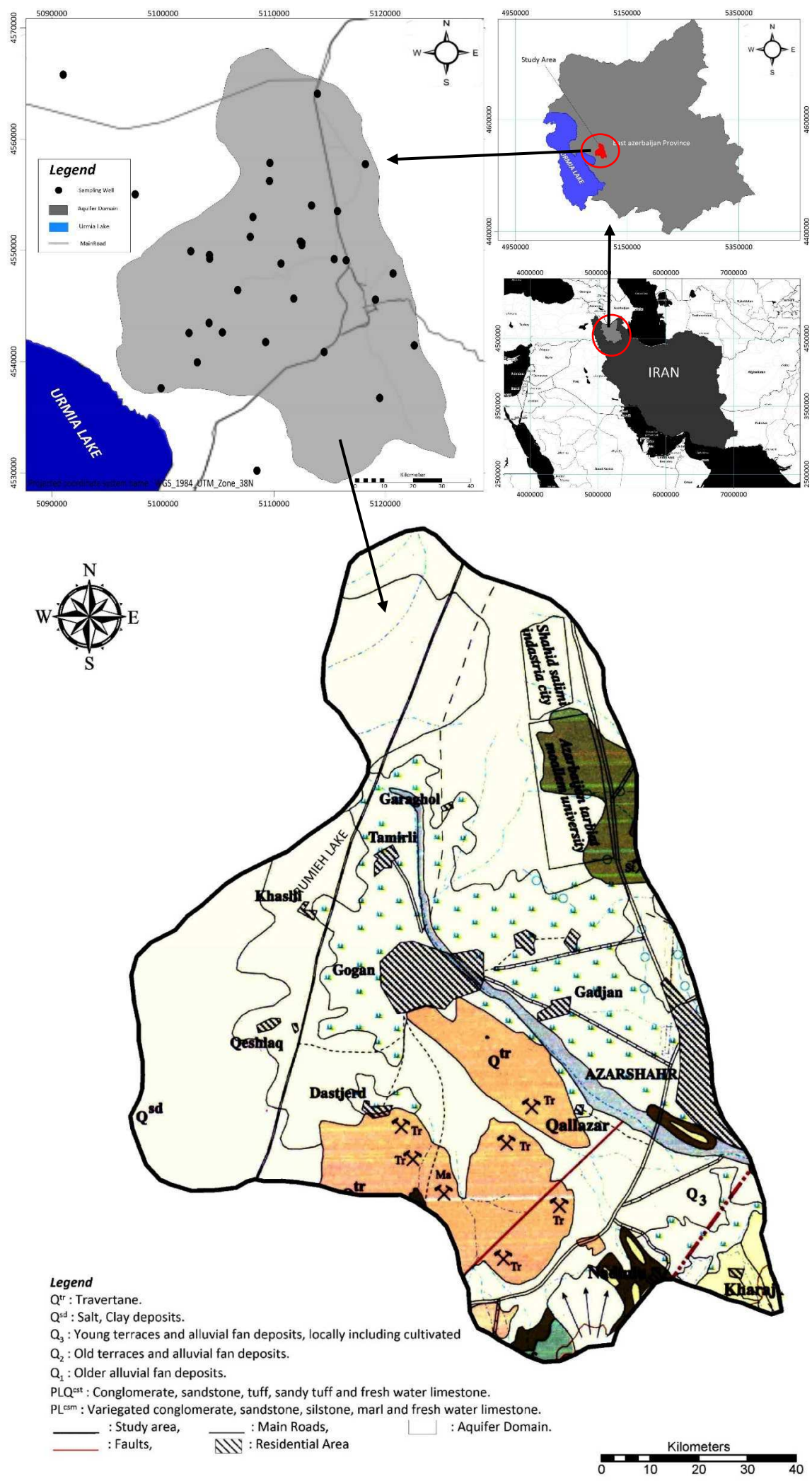

Fig. 1 


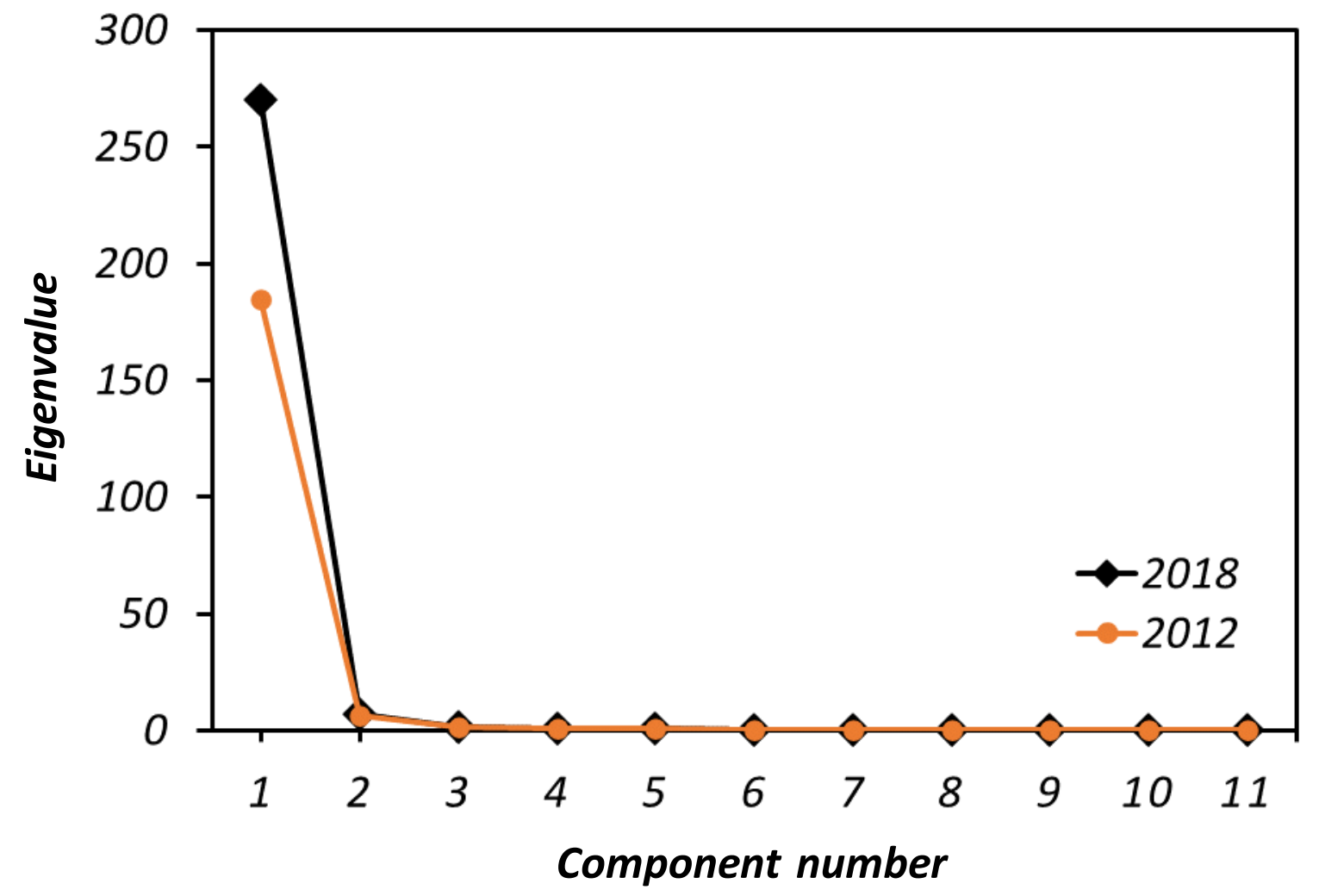

Fig. 2 

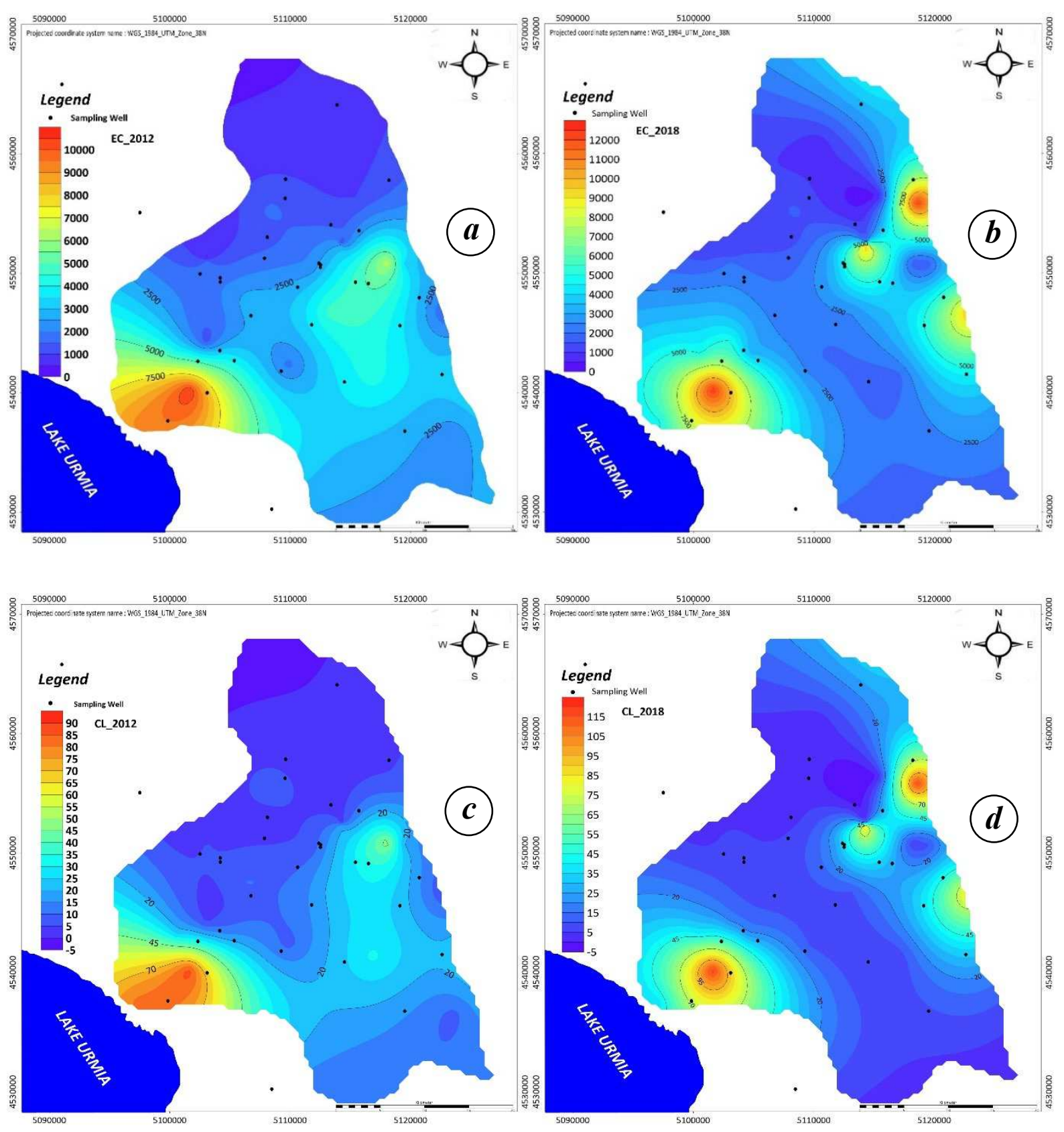

Fig. 3 

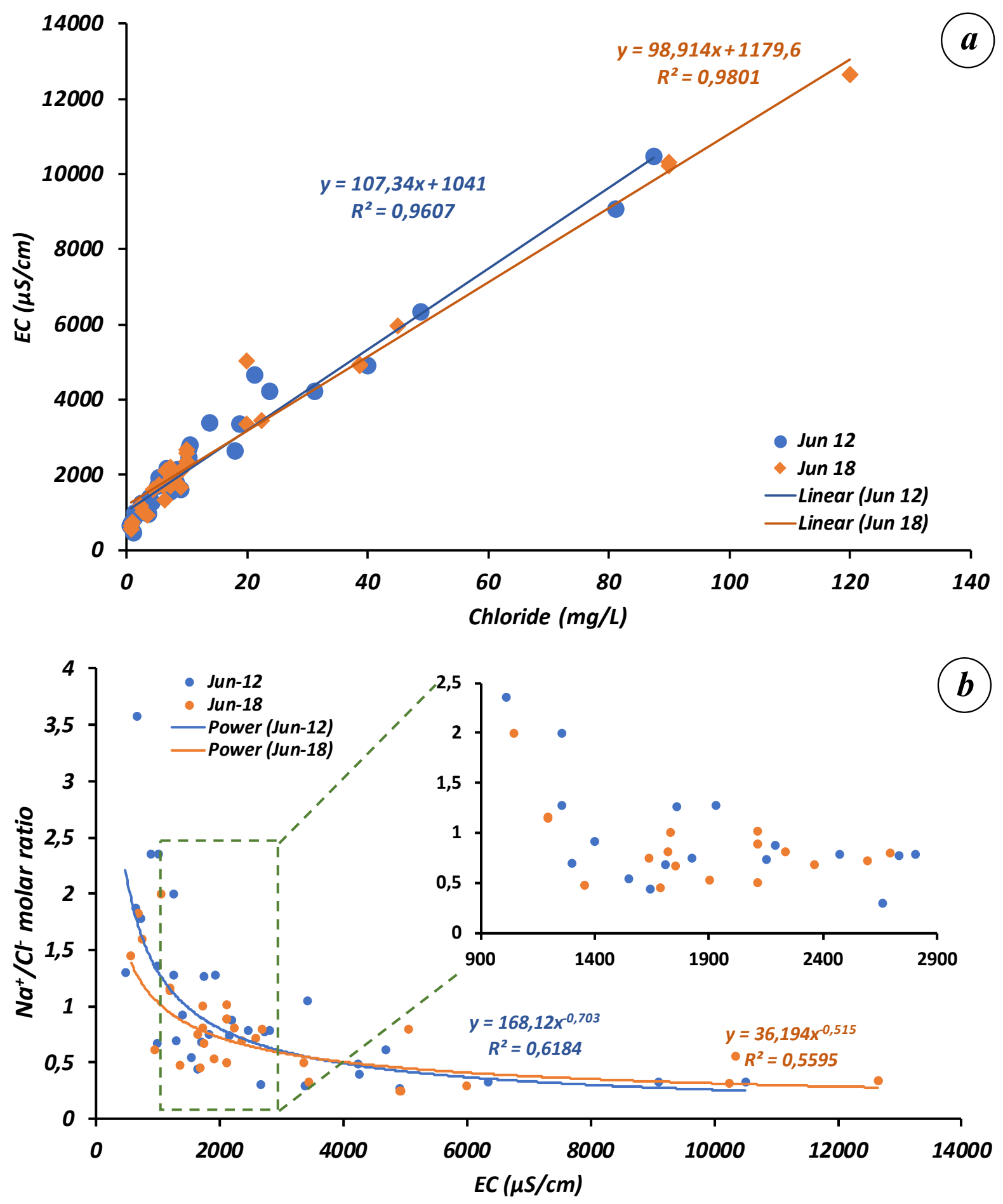

Fig. 4 

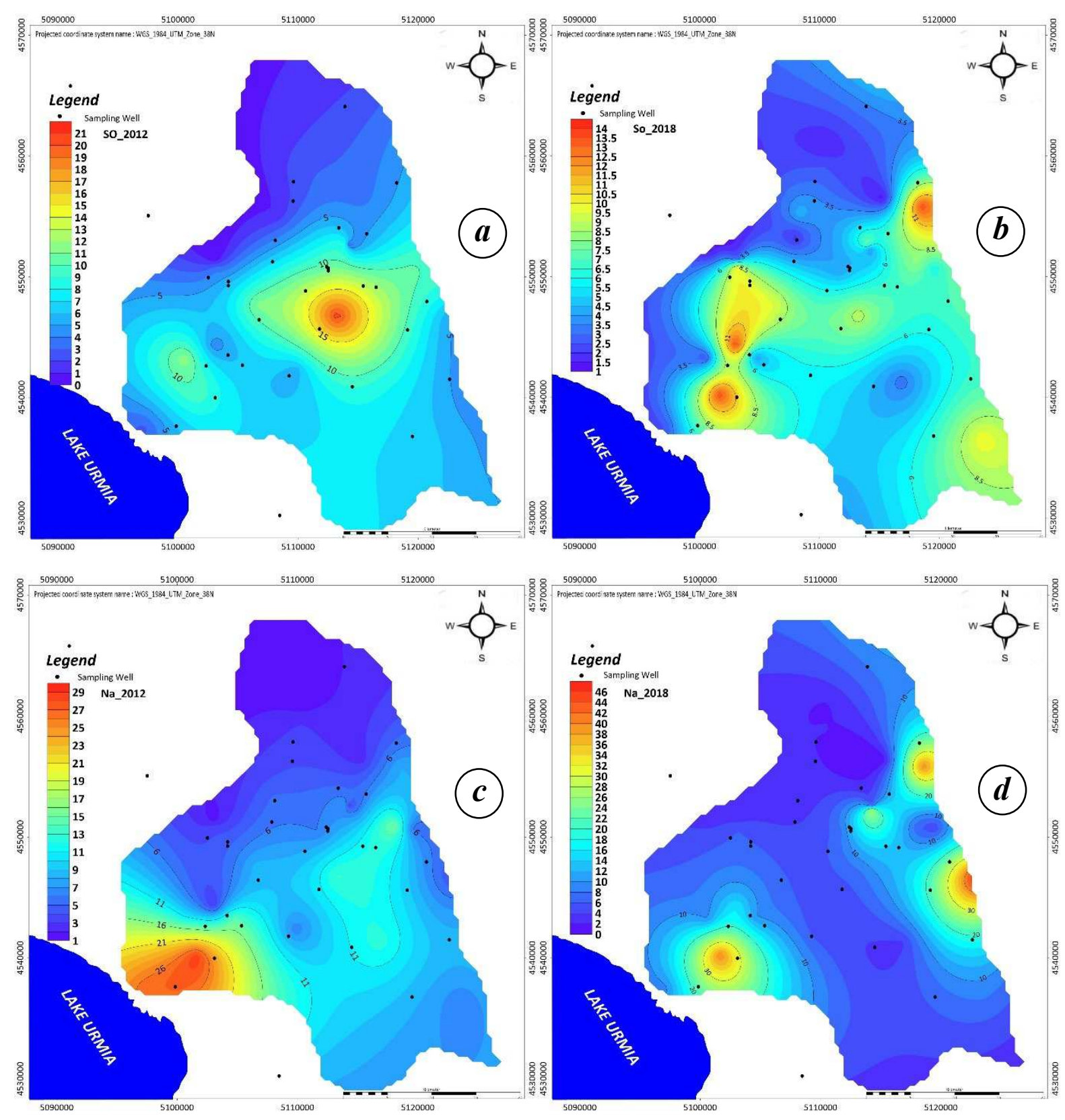

Fig. 5 

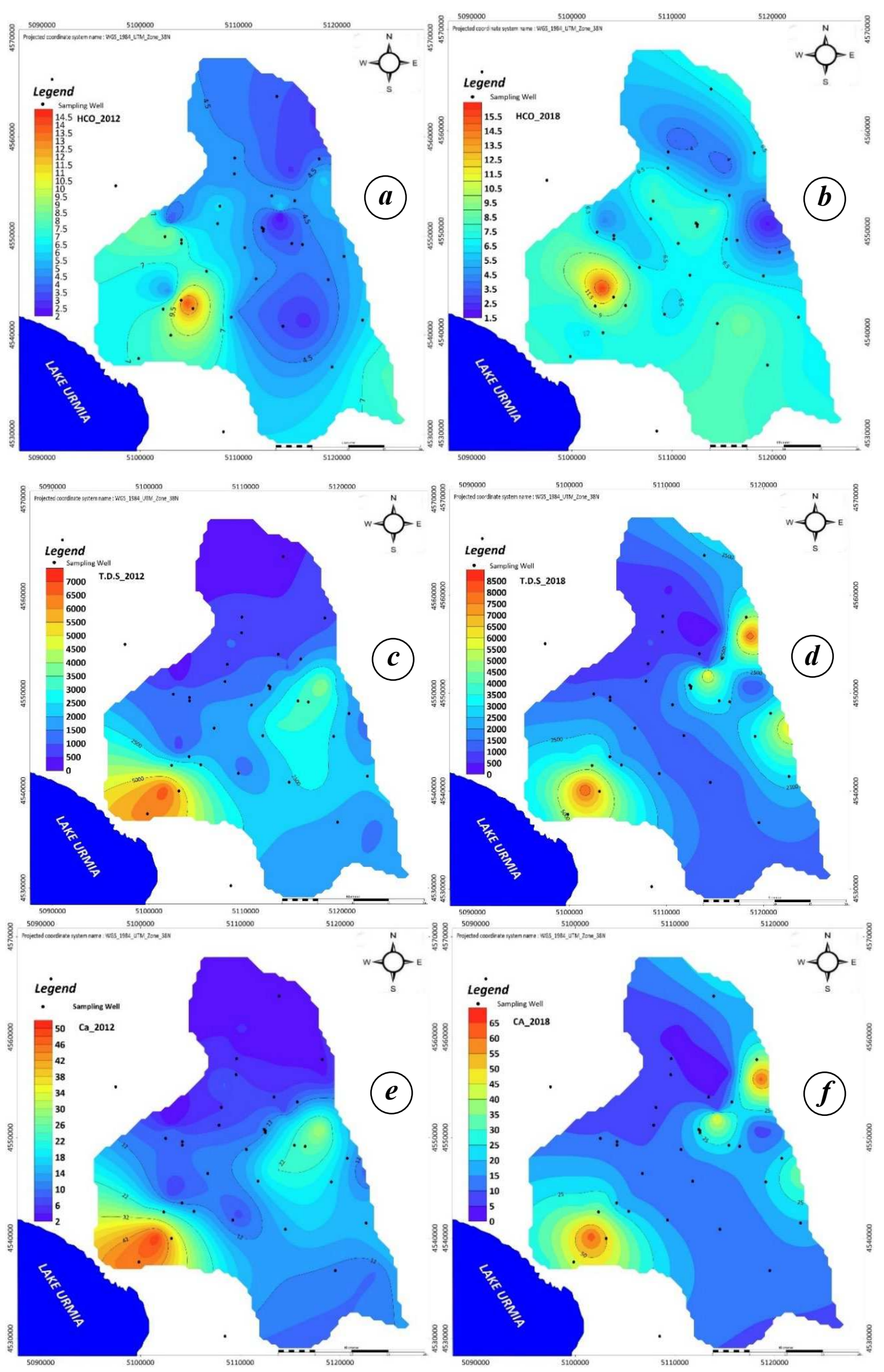

Fig. 6 

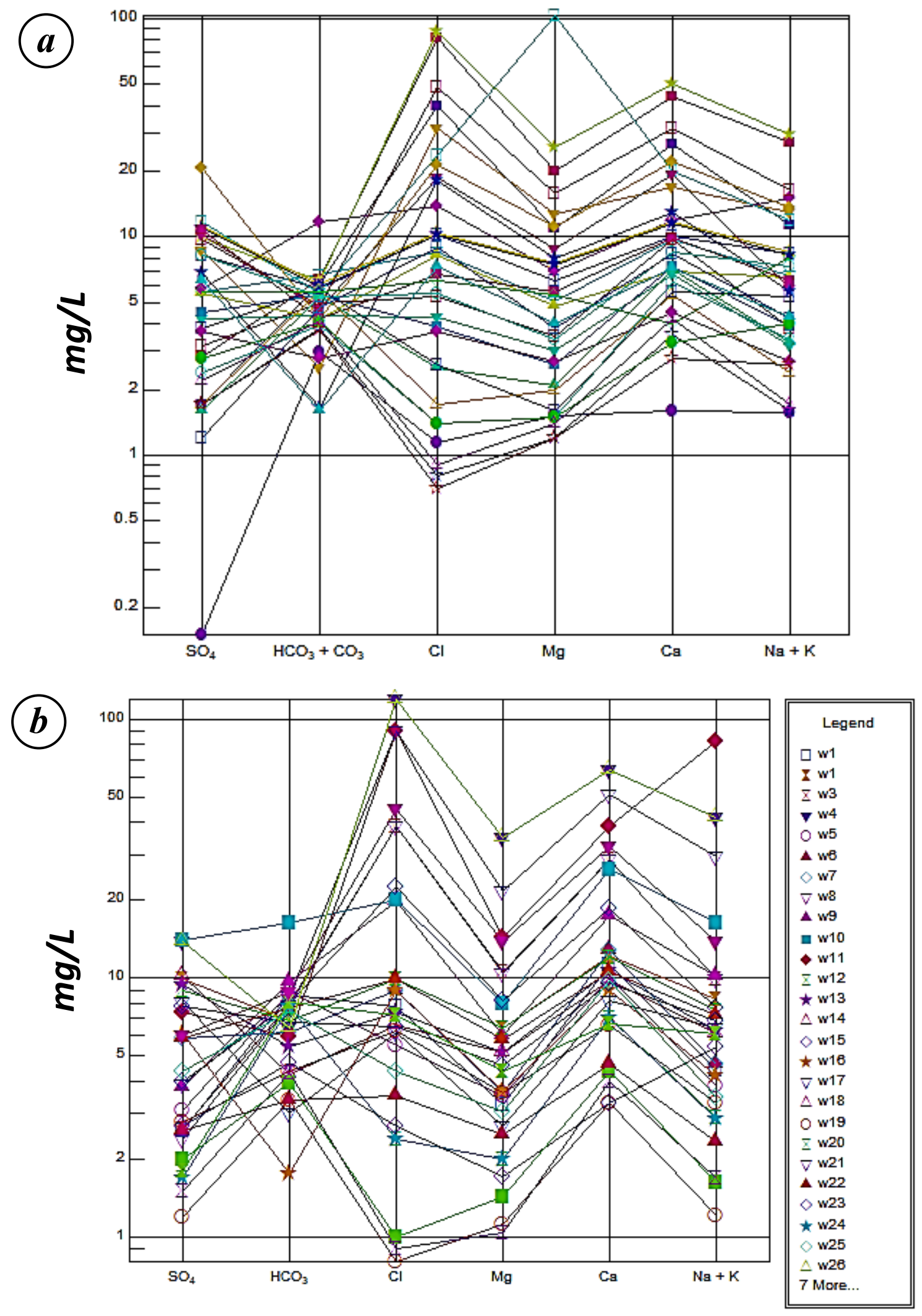

Fig. 7 

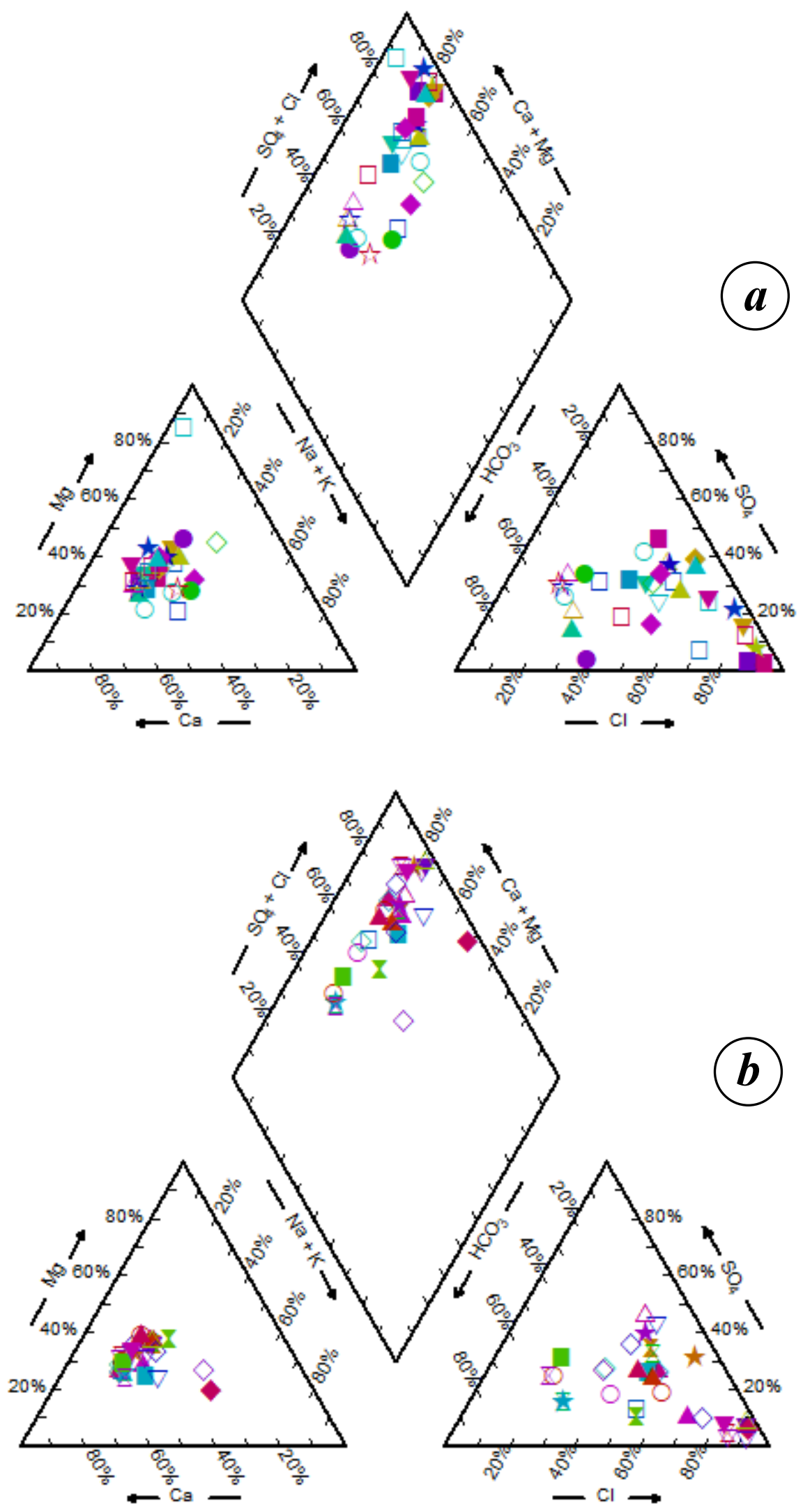

Fig. 8 

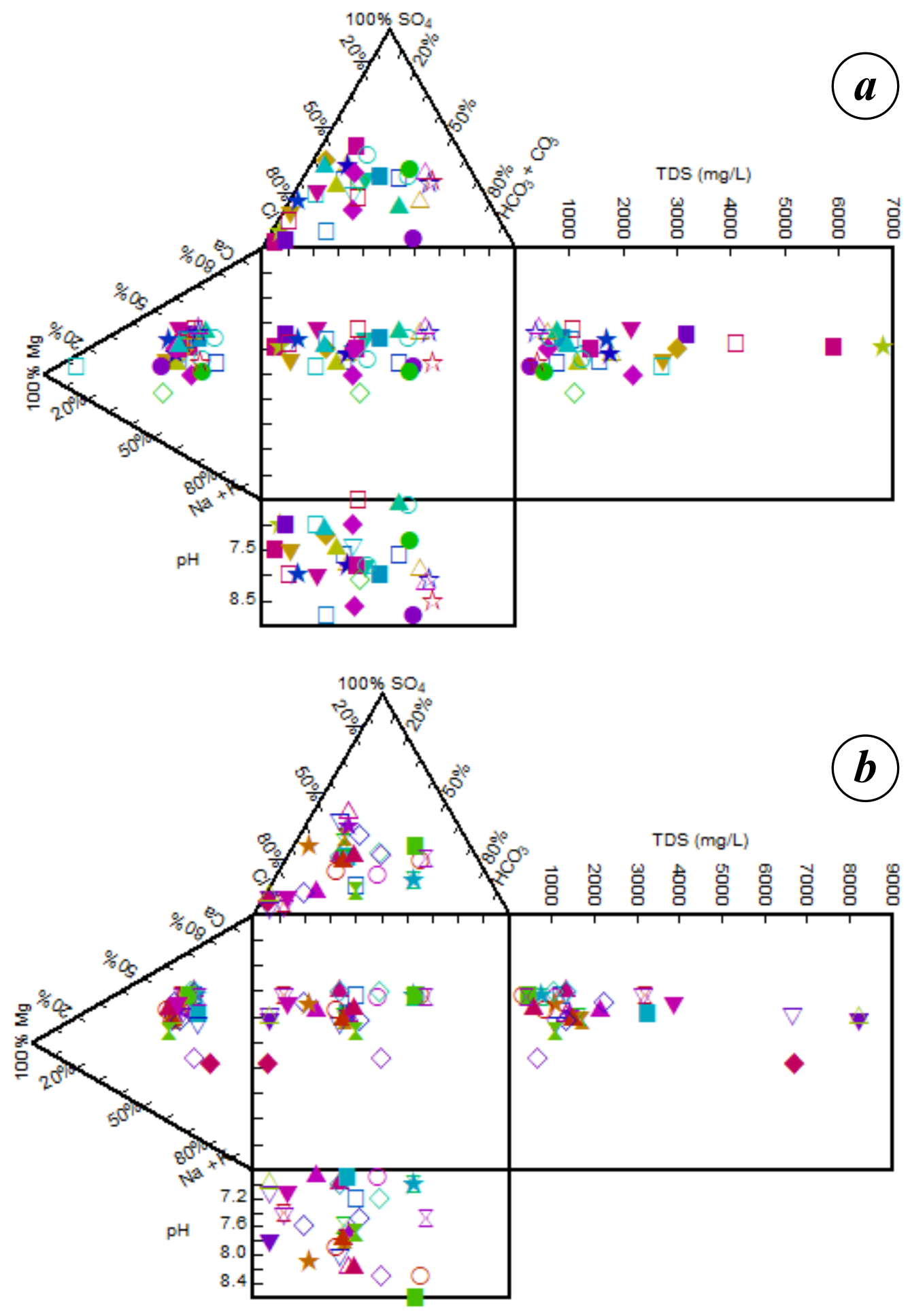

Fig. 9 

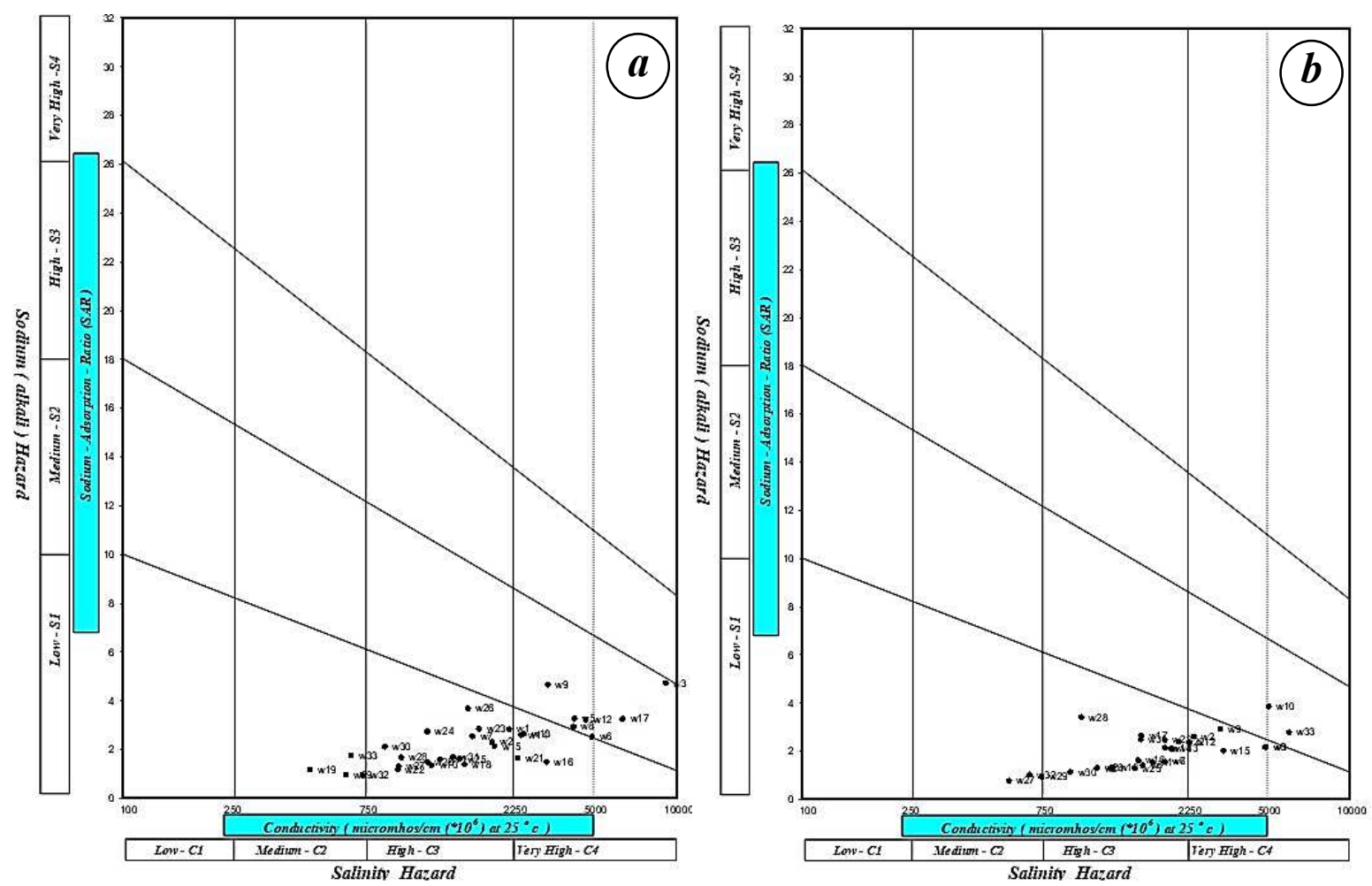

Fig. 10 

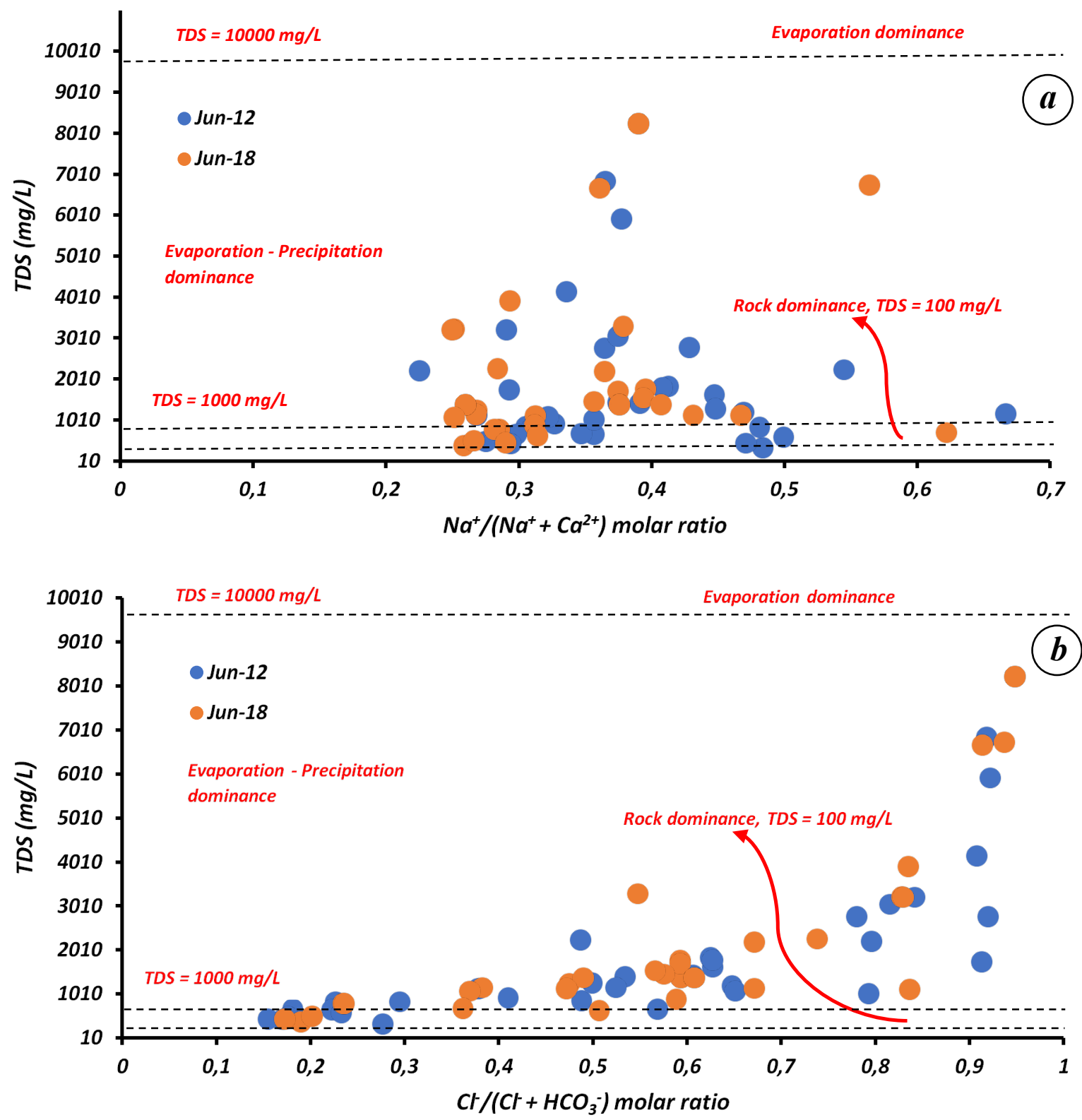

Fig. 11 

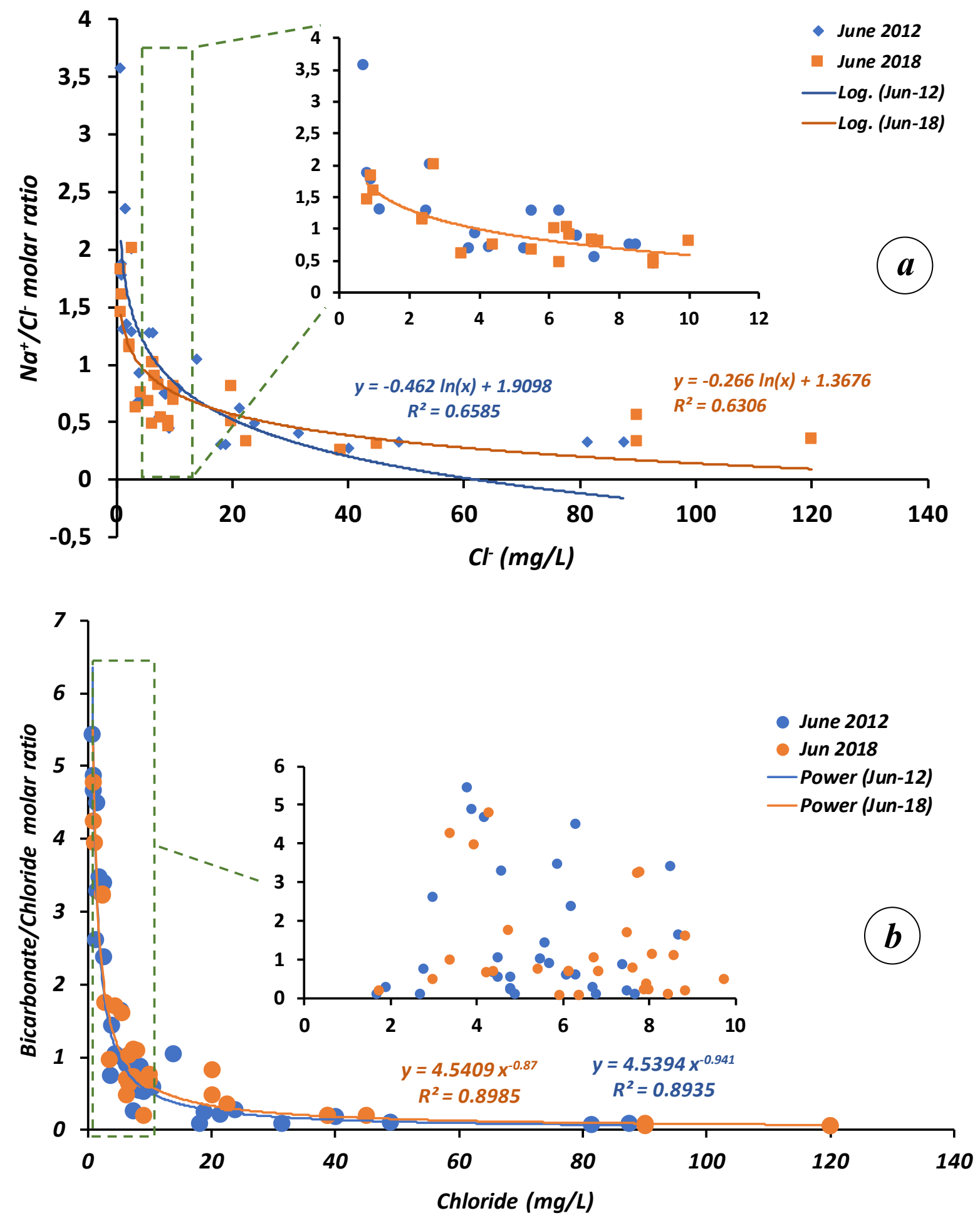

Fig. 12 

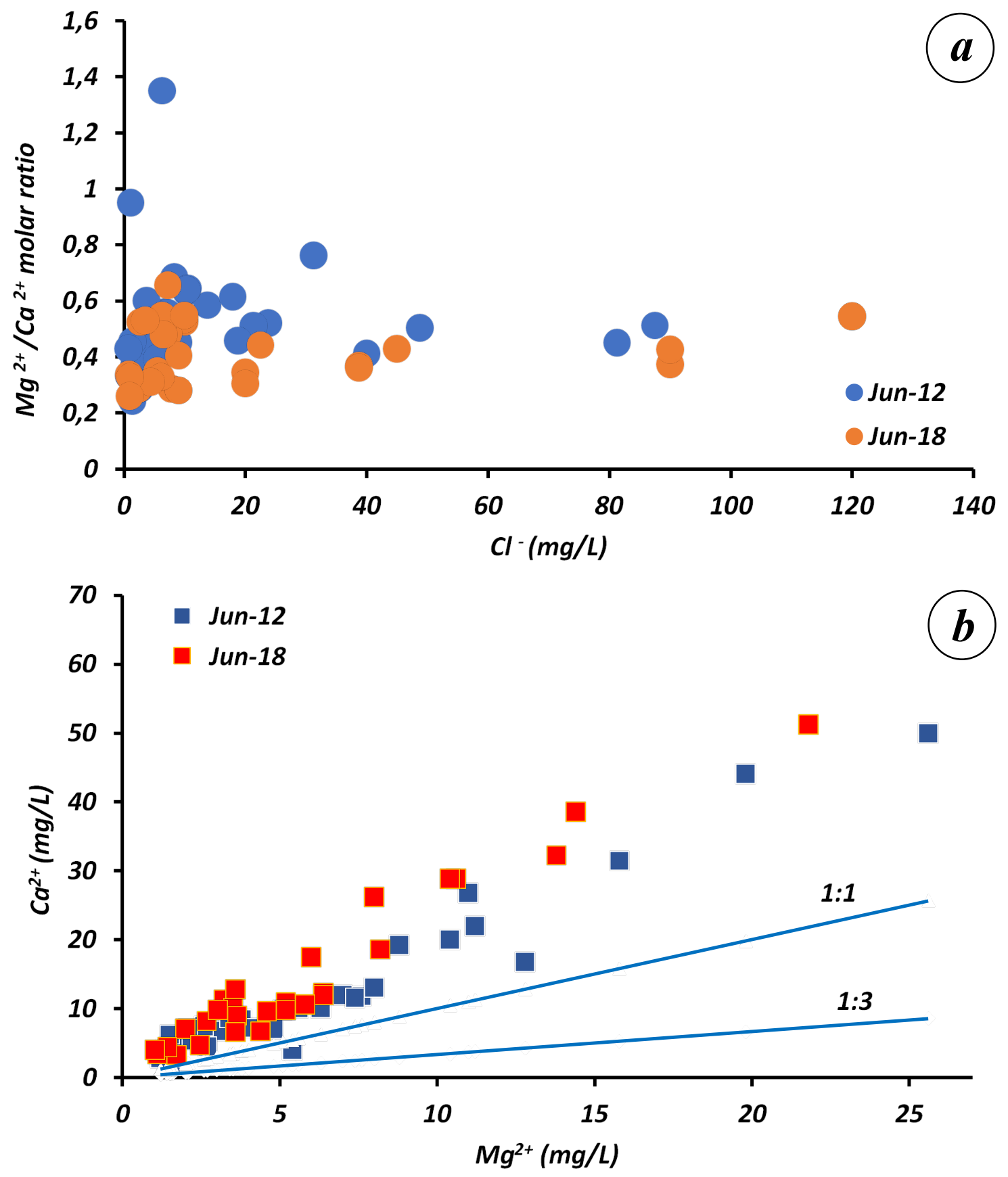

Fig. 13 


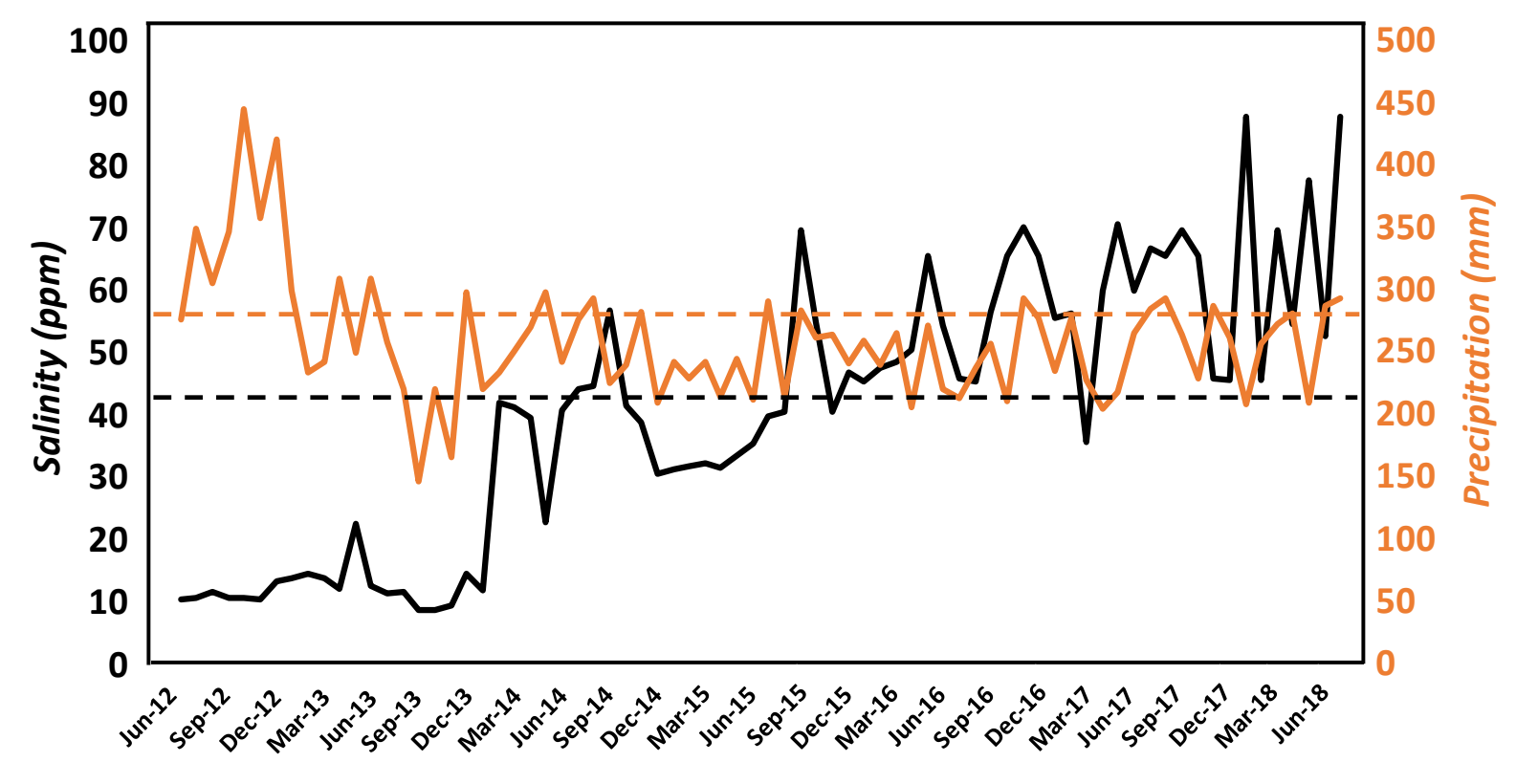

Fig. 14 


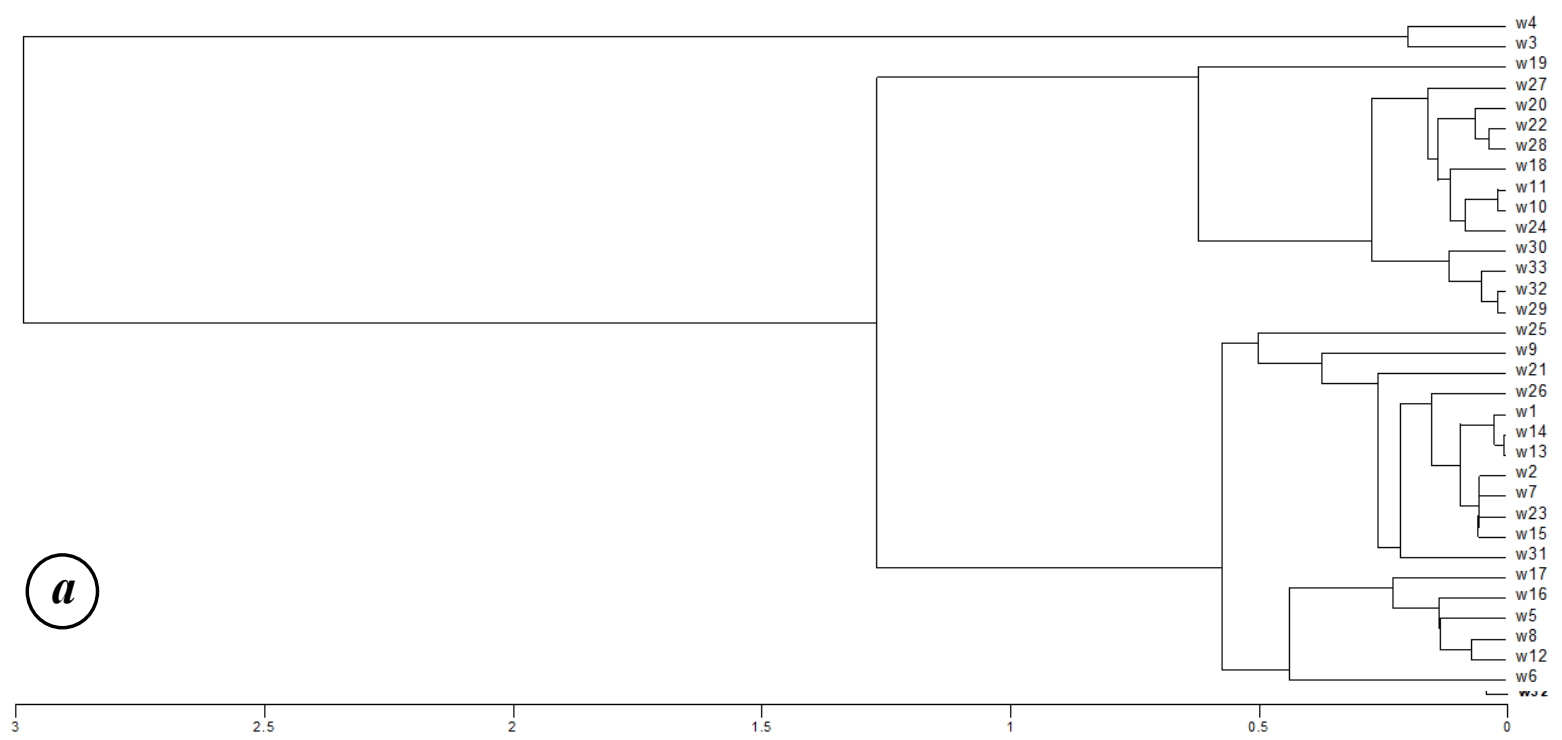

Square Euclidean - Data log(10) transformed

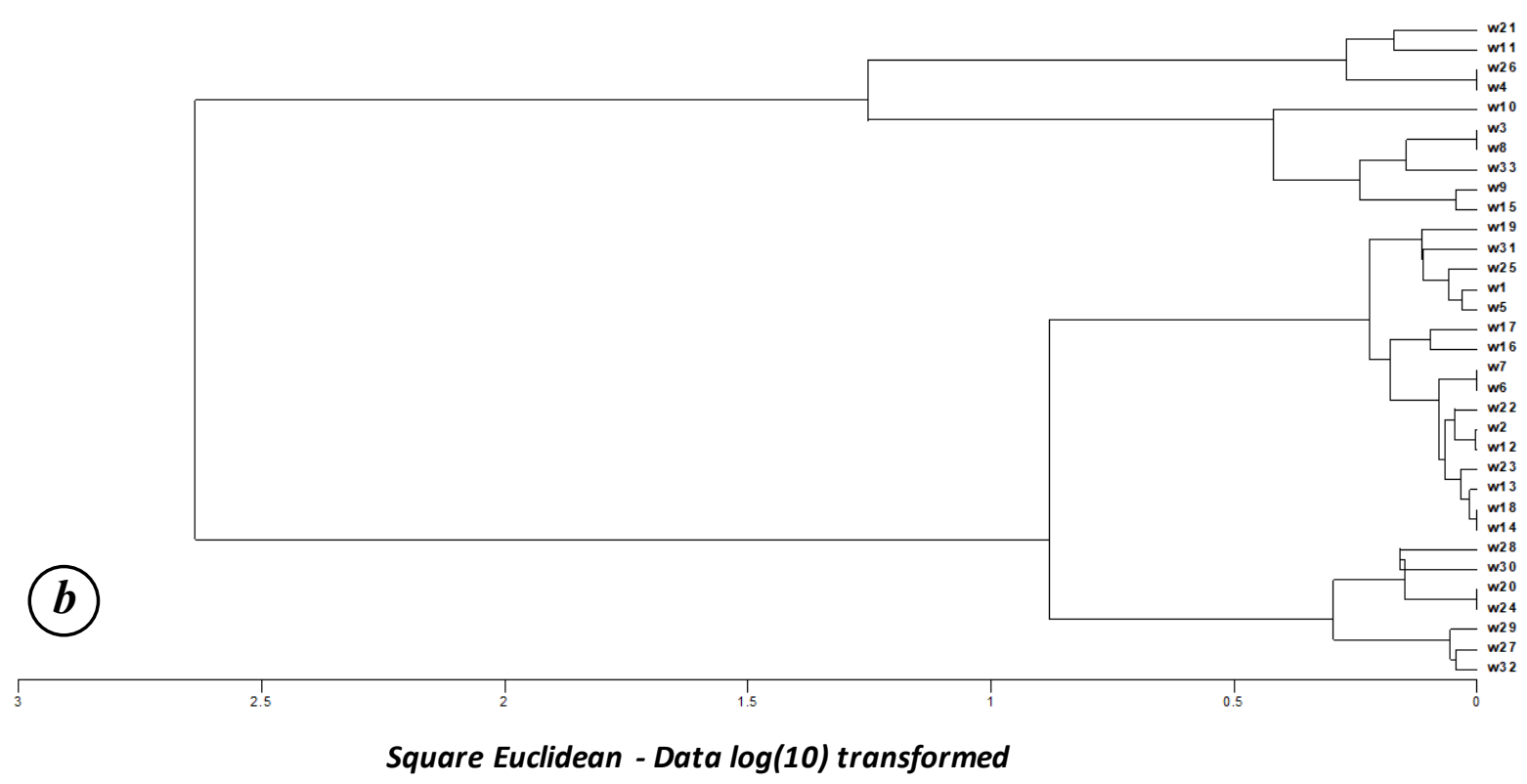

Fig. 15 


\section{TABLES}

Table 1 Statistical characteristics of different chemical components of Azarshahr Plain in June 2012 and 2018

\begin{tabular}{|c|c|c|c|c|c|c|}
\hline \multirow{2}{*}{ Parameter } & \multicolumn{3}{|c|}{ June 2012} & \multicolumn{3}{|c|}{ June 2018} \\
\hline & Minimum & Maximum & Average & Minimum & Maximum & Average \\
\hline $\mathrm{pH}$ & 6.5 & 8.8 & 7.8 & 6.9 & 8.6 & 7.6 \\
\hline $\begin{array}{l}\text { Alkalinity } \\
(\mathrm{mg} / \mathrm{L})\end{array}$ & 38.4 & 681.9 & 360.15 & 29.02 & 1162.48 & 595.75 \\
\hline $\begin{array}{l}\text { Hardness } \\
(\mathrm{mg} / \mathrm{L})\end{array}$ & 154.96 & 3761.13 & 1958.04 & 221.11 & 4914.58 & 2567.84 \\
\hline $\begin{array}{l}\text { Conductivity } \\
(\mu \mathrm{S} / \mathrm{cm})\end{array}$ & 307.45 & 6825 & 1185.6 & 567 & 12650 & 2110 \\
\hline TDS (mg/L) & 10500 & 473 & 1824 & 368.55 & 8222.5 & 1371.5 \\
\hline $\begin{array}{l}\text { Sodium } \\
(\mathrm{mg} / \mathrm{L})\end{array}$ & 1.5 & 28.8 & 5.6 & 1.16 & 50 & 5.9 \\
\hline $\begin{array}{l}\text { Potassium } \\
(\mathrm{mg} / \mathrm{L})\end{array}$ & 0.007 & 0.7 & 0.3 & 0.03 & 0.45 & 0.22 \\
\hline $\begin{array}{l}\text { Calcium } \\
(\mathrm{mg} / \mathrm{L})\end{array}$ & 1.6 & 50 & 8.6 & 3.28 & 64 & 10.6 \\
\hline $\begin{array}{l}\text { Magnesium } \\
(\mathrm{mg} / \mathrm{L})\end{array}$ & 1.2 & 25.6 & 4.8 & 1.04 & 34.8 & 4.6 \\
\hline $\begin{array}{l}\text { Chloride } \\
(\mathrm{mg} / \mathrm{L})\end{array}$ & 0.7 & 87.5 & 7.3 & 0.8 & 120 & 7.8 \\
\hline $\begin{array}{l}\text { Sulfate } \\
(\mathrm{mg} / \mathrm{L})\end{array}$ & 0.15 & 20.8 & 5.5 & 1.2 & 14 & 4.4 \\
\hline $\begin{array}{l}\text { Carbonate } \\
(\mathrm{mg} / \mathrm{L})\end{array}$ & 0 & 1.4 & 0 & 0 & 0.5 & 0 \\
\hline $\begin{array}{l}\text { Bicarbonate } \\
(\mathrm{mg} / \mathrm{L})\end{array}$ & 1.7 & 14.5 & 5.5 & 1.75 & 16.45 & 6.75 \\
\hline
\end{tabular}

*Alkalinity is due to the presence of bicarbonates only, alkalinity due to hydroxide and carbonate is neglected. 
Table 2 Groundwater quality parameters in the Azarshahr Basin during June 2012 and June 2018

\begin{tabular}{|c|c|c|c|c|c|c|c|}
\hline \multirow[b]{2}{*}{$\begin{array}{l}\text { Water } \\
\text { quality } \\
\text { parameter }\end{array}$} & \multirow[b]{2}{*}{$\begin{array}{l}\text { WHO } \\
\text { standard } \\
\text { value }\end{array}$} & \multicolumn{3}{|c|}{ June 2012} & \multicolumn{3}{|c|}{ June 2018} \\
\hline & & $\begin{array}{l}\text { Experimental } \\
\text { value (range) }\end{array}$ & $\begin{array}{l}\text { Mean } \\
\text { Value } \\
(n=33)\end{array}$ & Description & $\begin{array}{l}\text { Experimental } \\
\text { value (range) }\end{array}$ & $\begin{array}{l}\text { Mean Value } \\
(n=33)\end{array}$ & Description \\
\hline $\mathrm{pH}$ & $6.5-8.5$ & $6.5-8.8$ & 7.64 & $\begin{array}{l}\text { Satisfactory } \\
\text { for all } \\
\text { samples }\end{array}$ & $6.9-8.6$ & 7.58 & $\begin{array}{l}\text { Satisfactory for } \\
\text { all samples }\end{array}$ \\
\hline $\begin{array}{l}\mathrm{EC} \\
(\mu \mathrm{S} / \mathrm{cm})\end{array}$ & 1400 & $473-10,500$ & 2660 & $\begin{array}{l}\text { Too much } \\
\text { for } 63 \% \text { of } \\
\text { samples }\end{array}$ & $567-12,650$ & 3398 & $\begin{array}{l}\text { Too much for } \\
75 \% \text { of samples }\end{array}$ \\
\hline $\begin{array}{l}\text { TDS } \\
(\mathrm{mg} / \mathrm{L})\end{array}$ & 1000 & $307.45-6825$ & 1729 & $\begin{array}{l}\text { Too much } \\
\text { for } 57 \% \text { of } \\
\text { samples }\end{array}$ & $368.6-8223$ & 2209 & $\begin{array}{l}\text { Too much for } \\
72 \% \text { of samples }\end{array}$ \\
\hline $\mathrm{TH}(\mathrm{mg} / \mathrm{L})$ & 500 & $155-3761$ & 107.5 & $\begin{array}{l}\text { Too much } \\
\text { for } 54 \% \text { of } \\
\text { samples }\end{array}$ & $221-4914$ & 1152 & $\begin{array}{l}\text { Too much for } \\
74 \% \text { of samples }\end{array}$ \\
\hline $\mathrm{Cl}^{-}(\mathrm{mg} / \mathrm{L})$ & 250 & $0.7-87.5$ & 15.08 & $\begin{array}{l}\text { Satisfactory } \\
\text { for all } \\
\text { samples }\end{array}$ & $0.8-120$ & 22.43 & $\begin{array}{l}\text { Satisfactory for } \\
\text { all samples }\end{array}$ \\
\hline $\mathrm{Na}^{+}(\mathrm{mg} / \mathrm{L})$ & 200 & $1.5-28.8$ & 7.57 & $\begin{array}{l}\text { Satisfactory } \\
\text { for all } \\
\text { samples }\end{array}$ & $1.16-50$ & 10 & $\begin{array}{l}\text { Satisfactory for } \\
\text { all samples }\end{array}$ \\
\hline $\mathrm{K}^{+}(\mathrm{mg} / \mathrm{L})$ & - & $0.07-0.7$ & 0.26 & $\begin{array}{l}\text { No } \\
\text { comparison }\end{array}$ & $0.03-0.45$ & 0.21 & No comparison \\
\hline $\begin{array}{l}\mathrm{SO}_{4}{ }^{2-} \\
(\mathrm{mg} / \mathrm{L})\end{array}$ & 400 & $0.15-20.8$ & 195.45 & $\begin{array}{l}\text { Satisfactory } \\
\text { for all } \\
\text { samples }\end{array}$ & $1.2-14$ & 5.70 & $\begin{array}{l}\text { Satisfactory for } \\
\text { all samples }\end{array}$ \\
\hline
\end{tabular}


Table 3 Correlation matrix of chemical constituents of groundwater of Azarshahr aquifer in June 2012 and 2018

\begin{tabular}{|c|c|c|c|c|c|c|c|c|c|c|c|}
\hline $\begin{array}{l}\text { (a) } 2012 \\
(n=33)\end{array}$ & & & & & & & & & & & \\
\hline & $\mathrm{EC}$ & T.D.S & $\mathrm{pH}$ & $\mathrm{Ca}^{2+}$ & $\mathrm{Mg}^{2+}$ & $\mathrm{Na}^{+}$ & $\mathrm{K}^{+}$ & $\mathrm{HCO}_{3}{ }^{-}$ & $\mathrm{CO}_{3}{ }^{2-}$ & $\mathrm{Cl}-$ & $\mathrm{SO}_{4}{ }^{2-}$ \\
\hline $\mathrm{EC}$ & 1 & & & & & & & & & & \\
\hline TDS & 0.96870 & 1 & & & & & & & & & \\
\hline $\mathrm{pH}$ & -0.29742 & -0.29742 & 1 & & & & & & & & \\
\hline $\mathrm{Ca}^{2+}$ & 0.988774 & 0.988774 & -0.30403 & 1 & & & & & & & \\
\hline $\mathrm{Mg}^{2+}$ & 0.986829 & 0.986829 & -0.24896 & 0.967259 & 1 & & & & & & \\
\hline $\mathrm{Na}^{+}$ & 0.971054 & 0.971054 & -0.31476 & 0.930585 & 0.949899 & 1 & & & & & \\
\hline $\mathrm{K}^{+}$ & 0.53224 & 0.532239 & -0.37716 & 0.485839 & 0.509488 & 0.580988 & 1 & & & & \\
\hline $\mathrm{HCO}_{3}^{-}$ & 0.265297 & 0.265296 & -0.55437 & 0.240915 & 0.181128 & 0.360564 & 0.341863 & 1 & & & \\
\hline $\mathrm{CO}_{3}{ }^{2-}$ & -0.19698 & -0.19698 & 0.557689 & -0.18436 & -0.19203 & -0.21141 & -0.20172 & -0.20178 & 1 & & \\
\hline $\mathrm{Cl}^{-}$ & 0.980162 & 0.980162 & -0.23184 & 0.978821 & 0.963313 & 0.940086 & 0.465545 & 0.182468 & $\begin{array}{c}- \\
0.13994\end{array}$ & 1 & \\
\hline $\mathrm{SO}_{4}{ }^{2-}$ & 0.424509 & 0.424509 & -0.18514 & 0.383385 & 0.482307 & 0.414548 & 0.397468 & -0.01196 & $\begin{array}{c}- \\
0.31157\end{array}$ & 0.264557 & 1 \\
\hline \multicolumn{12}{|l|}{$\begin{array}{l}\text { (b) } 2018 \\
(n=33)\end{array}$} \\
\hline & $\mathrm{EC}$ & T.D.S & $\mathrm{pH}$ & $\mathrm{Ca}^{2+}$ & $\mathrm{Mg}^{2+}$ & $\mathrm{Na}^{+}$ & $\mathrm{K}^{+}$ & $\mathrm{HCO}_{3}^{-}$ & $\mathrm{CO}_{3}{ }^{2-}$ & $\mathrm{Cl}-$ & $\mathrm{SO}_{4}{ }^{2-}$ \\
\hline $\mathrm{EC}$ & 1 & & & & & & & & & & \\
\hline T.D.S & 0.89652 & 1 & & & & & & & & & \\
\hline $\mathrm{pH}$ & -0.32607 & -0.32608 & 1 & & & & & & & & \\
\hline $\mathrm{Ca}^{2+}$ & 0.98592 & 0.985925 & -0.37894 & 1 & & & & & & & \\
\hline $\mathrm{Mg}^{2+}$ & 0.959651 & 0.959661 & -0.26362 & 0.972897 & 1 & & & & & & \\
\hline $\mathrm{Na}^{+}$ & 0.955657 & 0.955647 & -0.22979 & 0.896171 & 0.871471 & 1 & & & & & \\
\hline $\mathrm{K}^{+}$ & 0.737686 & 0.737699 & -0.3883 & 0.747539 & 0.721873 & 0.635601 & 1 & & & & \\
\hline $\mathrm{HCO}_{3}^{-}$ & 0.262603 & 0.262608 & -0.70421 & 0.300123 & 0.186193 & 0.182215 & 0.375044 & 1 & & & \\
\hline $\mathrm{CO}_{3}{ }^{2-}$ & -0.23639 & -0.23641 & 0.53585 & -0.24528 & -0.21647 & -0.18776 & -0.51385 & -0.29265 & 1 & & \\
\hline $\mathrm{Cl}^{-}$ & 0.989999 & 0.989993 & -0.27168 & 0.977818 & 0.965508 & 0.945988 & 0.69445 & 0.163293 & $\begin{array}{c}- \\
0.18972\end{array}$ & 1 & \\
\hline $\mathrm{SO}_{4}^{2-}$ & 0.522702 & 0.522763 & -0.08002 & 0.50324 & 0.553636 & 0.525629 & 0.49057 & 0.15671 & $\begin{array}{c}- \\
0.29275\end{array}$ & 0.449915 & 1 \\
\hline
\end{tabular}


Table 4 Percentage of Schoeller classification for drinking at Azarshahr aquifer in June 2012 and 2018

\begin{tabular}{|c|c|c|c|c|c|c|}
\hline \multicolumn{7}{|c|}{ June 2012} \\
\hline $\mathrm{SO}_{4}^{2-}$ & $\mathrm{Cl}^{-}$ & $\mathrm{Na}^{+}$ & $\mathrm{pH}$ & TH & TDS & Class \\
\hline 33.33 & 36.36 & 42.42 & 6.67 & 12.12 & 12.12 & Good \\
\hline 27.27 & 24.24 & 33.33 & 6.06 & 27.27 & 24.24 & Acceptable \\
\hline 36.36 & 18.18 & 18.18 & 8.18 & 33.33 & 36.36 & Medium \\
\hline 3.03 & 9.09 & 6.06 & 0 & 18.18 & 18.18 & Inappropriate \\
\hline 0 & 6.06 & 0 & 9.09 & 9.09 & 9.09 & $\begin{array}{c}\text { Totally } \\
\text { unpleasant }\end{array}$ \\
\hline 0 & 6.06 & 0 & 0 & 0 & 0 & Not drinkable \\
\hline \multicolumn{7}{|c|}{ June 2018} \\
\hline $\mathrm{SO}_{4}^{2-}$ & $\mathrm{Cl}^{-}$ & $\mathrm{Na}^{+}$ & $\mathrm{pH}$ & $\mathrm{TH}$ & TDS & Class \\
\hline 36.36 & 24.24 & 39.39 & 6.61 & 6.06 & 9.09 & Good \\
\hline 15.15 & 36.36 & 39.39 & 6.06 & 15.15 & 15.15 & Acceptable \\
\hline 39.39 & 9.09 & 9.09 & 4.24 & 48.48 & 45.45 & Medium \\
\hline 9.09 & 15.15 & 3.03 & 9.09 & 15.15 & 18.18 & Inappropriate \\
\hline 0 & 3.03 & 9.09 & 0 & 9.09 & 6.06 & $\begin{array}{c}\text { Totally } \\
\text { Unpleasant }\end{array}$ \\
\hline 0 & 12.12 & 0 & 0 & 6.06 & 6.06 & Not drinkable \\
\hline
\end{tabular}


Table 5 Percentage of each Wilcox classification class for agricultural and irrigation use in Azarshahr at June 2012 and June 2018

\begin{tabular}{|c|c|c|c|c|c|c|c|c|c|c|c|c|c|c|c|}
\hline \multicolumn{16}{|c|}{2012} \\
\hline \multicolumn{4}{|c|}{$\mathrm{C} 4$} & \multicolumn{4}{|c|}{ C3 } & \multicolumn{4}{|c|}{$\mathrm{C} 2$} & \multicolumn{4}{|c|}{$\mathrm{C} 1$} \\
\hline S4 & S3 & S2 & $\mathrm{S} 1$ & $\mathrm{~S} 4$ & S3 & S2 & S1 & S4 & $\mathrm{S} 3$ & S2 & S1 & S4 & $\mathrm{S} 3$ & S2 & $\mathrm{S} 1$ \\
\hline 0 & 3.03 & 21.21 & 15.15 & 48.48 & 0 & 0 & 0 & 0 & 0 & 0 & 12.12 & 0 & 0 & 0 & 0 \\
\hline \multicolumn{16}{|c|}{2018} \\
\hline \multicolumn{4}{|c|}{$\mathrm{C} 4$} & \multicolumn{4}{|c|}{$\mathrm{C} 3$} & \multicolumn{4}{|c|}{$\mathrm{C} 2$} & \multicolumn{4}{|c|}{$\mathrm{C} 1$} \\
\hline $\mathrm{S} 4$ & $\mathrm{~S} 3$ & S2 & S1 & S4 & S3 & S2 & S1 & S4 & $\mathrm{S} 3$ & S2 & S1 & S4 & S3 & S2 & $\mathrm{S} 1$ \\
\hline 3.03 & 9.09 & 6.06 & 21.21 & 0 & 0 & 0 & 51.52 & 0 & 0 & 0 & 9.09 & 0 & 0 & 0 & 0 \\
\hline
\end{tabular}


Table 6 Water quality classification for agricultural and irrigation applications in Azarshahr aquifer in 2012

\begin{tabular}{|c|c|c|c|c|c|c|}
\hline \multirow{2}{*}{ Station } & \multicolumn{2}{|c|}{$\begin{array}{c}\text { Geographical location } \\
(\mathrm{m})\end{array}$} & \multirow{2}{*}{ SAR } & \multirow{2}{*}{$\begin{array}{c}\mathrm{EC} \\
(\mu \mathrm{S} / \mathrm{cm})\end{array}$} & \multirow{2}{*}{$\begin{array}{l}\text { Class of } \\
\text { water for } \\
\text { irrigation }\end{array}$} & \multirow{2}{*}{ Description } \\
\hline & Longitude & Latitude & & & & \\
\hline w1 & 5100286 & 4541268 & 2.84 & 2470 & C4-S1 & $\begin{array}{l}\text { Very salty - inappropriate for } \\
\text { irrigation }\end{array}$ \\
\hline w2 & 5121019 & 4546089 & 2.31 & 2150 & $\mathrm{C} 3-\mathrm{S} 1$ & Salty - can be used for agriculture \\
\hline w3 & 5098933 & 4566897 & 4.73 & 9090 & $\mathrm{C} 4-\mathrm{S} 2$ & $\begin{array}{l}\text { Very salty - inappropriate for } \\
\text { irrigation }\end{array}$ \\
\hline w4 & 5095698 & 4555891 & 4.68 & 10500 & $\mathrm{C} 4-\mathrm{S} 3$ & $\begin{array}{l}\text { Very salty - inappropriate for } \\
\text { irrigation }\end{array}$ \\
\hline w5 & 5108711 & 4539922 & 3.28 & 4250 & $\mathrm{C} 4-\mathrm{S} 2$ & $\begin{array}{l}\text { Very salty - inappropriate for } \\
\text { irrigation }\end{array}$ \\
\hline w6 & 5108965 & 4543479 & 2.53 & 4920 & $\mathrm{C} 4-\mathrm{S} 2$ & $\begin{array}{l}\text { Very salty - inappropriate for } \\
\text { irrigation }\end{array}$ \\
\hline w7 & 5101025 & 4542054 & 2.55 & 1824 & $\mathrm{C} 3-\mathrm{S} 1$ & Salty - can be used for agriculture \\
\hline w8 & 5115698 & 4549892 & 2.95 & 4230 & $\mathrm{C} 4-\mathrm{S} 2$ & $\begin{array}{l}\text { Very salty - inappropriate for } \\
\text { irrigation }\end{array}$ \\
\hline w9 & 5104236 & 4548762 & 4.67 & 3410 & $\mathrm{C} 4-\mathrm{S} 2$ & $\begin{array}{l}\text { Very salty - inappropriate for } \\
\text { irrigation }\end{array}$ \\
\hline w10 & 5105689 & 4551052 & 1.36 & 1299 & $\mathrm{C} 3-\mathrm{S} 1$ & Salty - can be used for agriculture \\
\hline w11 & 5108721 & 4550112 & 1.61 & 1396 & $\mathrm{C} 3-\mathrm{S} 1$ & Salty - can be used for agriculture \\
\hline w12 & 5105232 & 4548562 & 3.24 & 4680 & $\mathrm{C} 4-\mathrm{S} 2$ & $\begin{array}{l}\text { Very salty - inappropriate for } \\
\text { irrigation }\end{array}$ \\
\hline w13 & 5108871 & 4551096 & 2.66 & 2800 & $\mathrm{C} 4-\mathrm{S} 1$ & $\begin{array}{l}\text { Very salty - inappropriate for } \\
\text { irrigation }\end{array}$ \\
\hline w14 & 5109891 & 4555971 & 2.60 & 2730 & C4-S1 & $\begin{array}{l}\text { Very salty - inappropriate for } \\
\text { irrigation }\end{array}$ \\
\hline w15 & 5109820 & 4558455 & 2.15 & 2190 & $\mathrm{C} 3-\mathrm{S} 1$ & Salty - Can be used for agriculture \\
\hline w16 & 5108122 & 4530102 & 1.50 & 3380 & $\mathrm{C} 4-\mathrm{S} 1$ & $\begin{array}{l}\text { Very salty - inappropriate for } \\
\text { irrigation }\end{array}$ \\
\hline w17 & 5105462 & 4543965 & 3.27 & 6350 & $\mathrm{C} 4-\mathrm{S} 2$ & $\begin{array}{l}\text { Very salty - inappropriate for } \\
\text { irrigation }\end{array}$ \\
\hline w18 & 5107082 & 4546109 & 1.40 & 1708 & C3-S1 & Salty - can be used for agriculture \\
\hline w19 & 5109864 & 4540107 & 1.20 & 473 & $\mathrm{C} 2-\mathrm{S} 1$ & $\begin{array}{l}\text { Slightly salty - suitable for } \\
\text { agriculture }\end{array}$ \\
\hline w20 & 5110091 & 4549088 & 1.49 & 1253 & $\mathrm{C} 3-\mathrm{S} 1$ & Salty - can be used for agriculture \\
\hline w21 & 5111587 & 4545581 & 1.67 & 2660 & C4-S1 & $\begin{array}{l}\text { Very salty - inappropriate for } \\
\text { irrigation }\end{array}$ \\
\hline w22 & 5111802 & 4540092 & 1.20 & 981 & $\mathrm{C} 3-\mathrm{S} 1$ & Salty - can be used for agriculture \\
\hline w23 & 5111984 & 4549859 & 2.86 & 1928 & $\mathrm{C} 3-\mathrm{S} 1$ & Salty - can be used for agriculture \\
\hline w24 & 5112081 & 4553079 & 2.74 & 1253 & C3-S1 & Salty - can be used for agriculture \\
\hline w25 & 5114893 & 4540109 & 1.62 & 1640 & $\mathrm{C} 3-\mathrm{S} 1$ & Salty - can be used for agriculture \\
\hline w26 & 5115871 & 4549891 & 3.69 & 1755 & $\mathrm{C} 3-\mathrm{S} 1$ & Salty - can be used for agriculture \\
\hline w27 & 5117909 & 4549811 & 1.32 & 989 & $\mathrm{C} 3-\mathrm{S} 1$ & Salty - can be used for agriculture \\
\hline w28 & 5115086 & 4553809 & 1.68 & 1010 & $\mathrm{C} 3-\mathrm{S} 1$ & Salty - can be used for agriculture \\
\hline w29 & 5118255 & 4556857 & 0.97 & 638 & $\mathrm{C} 2-\mathrm{S} 1$ & Salty - can be used for agriculture \\
\hline w30 & 5119922 & 4546823 & 2.13 & 880 & $\mathrm{C} 3-\mathrm{S} 1$ & Salty - can be used for agriculture \\
\hline w31 & 5120109 & 4547891 & 1.69 & 1549 & $\mathrm{C} 3-\mathrm{S} 1$ & Salty - can be used for agriculture \\
\hline w32 & 5119986 & 4538092 & 0.96 & 731 & $\mathrm{C} 2-\mathrm{S} 1$ & $\begin{array}{l}\text { Slightly salty - suitable for } \\
\text { agriculture }\end{array}$ \\
\hline w33 & 5124687 & 4540071 & 1.77 & 665 & $\mathrm{C} 2-\mathrm{S} 1$ & $\begin{array}{l}\text { Slightly salty - suitable for } \\
\text { agriculture }\end{array}$ \\
\hline
\end{tabular}


Table 7 Water quality classification for agricultural and irrigation usage based on Wilcox criteria in Azarshahr aquifer in 2018

\begin{tabular}{|c|c|c|c|c|c|c|}
\hline \multirow{2}{*}{ Station } & \multicolumn{2}{|c|}{$\begin{array}{c}\text { Geographical location } \\
(\mathrm{m})\end{array}$} & \multirow{2}{*}{ SAR } & \multirow{2}{*}{$\begin{array}{c}\mathrm{EC} \\
(\mu \mathrm{S} / \mathrm{cm})\end{array}$} & \multirow{2}{*}{$\begin{array}{l}\text { Class of } \\
\text { water for } \\
\text { irrigation }\end{array}$} & \multirow{2}{*}{ Description } \\
\hline & Longitude & Latitude & & & & \\
\hline w1 & 5100286 & 4541268 & 1.54 & 1902 & $\mathrm{C} 3-\mathrm{S} 1$ & Salty - can be used for agriculture \\
\hline w2 & 5121019 & 4546089 & 2.62 & 2690 & $\mathrm{C} 4-\mathrm{S} 1$ & $\begin{array}{l}\text { Very salty - inappropriate for } \\
\text { irrigation }\end{array}$ \\
\hline w3 & 5098933 & 4566897 & 2.19 & 4940 & $\mathrm{C} 4-\mathrm{S} 1$ & $\begin{array}{l}\text { Very salty - inappropriate for } \\
\text { irrigation }\end{array}$ \\
\hline w4 & 5095698 & 4555891 & 5.83 & 12650 & $\mathrm{C} 4-\mathrm{S} 3$ & $\begin{array}{l}\text { Very salty - inappropriate for } \\
\text { irrigation }\end{array}$ \\
\hline w5 & 5108711 & 4539922 & 1.42 & 1749 & C3-S1 & Salty - can be used for agriculture \\
\hline w6 & 5108965 & 4543479 & 1.57 & 2110 & $\mathrm{C} 3-\mathrm{S} 1$ & Salty - can be used for agriculture \\
\hline w7 & 5101025 & 4542054 & 1.57 & 2110 & $\mathrm{C} 3-\mathrm{S} 1$ & Salty - can be used for agriculture \\
\hline w8 & 5115698 & 4549892 & 2.17 & 4910 & $\mathrm{C} 4-\mathrm{S} 1$ & $\begin{array}{l}\text { Very salty - inappropriate for } \\
\text { irrigation }\end{array}$ \\
\hline w9 & 5104236 & 4548762 & 2.92 & 3360 & $\mathrm{C} 4-\mathrm{S} 1$ & $\begin{array}{l}\text { Very salty - inappropriate for } \\
\text { irrigation }\end{array}$ \\
\hline w10 & 5105689 & 4551052 & 3.87 & 5050 & $\mathrm{C} 4-\mathrm{S} 2$ & $\begin{array}{l}\text { Very salty - inappropriate for } \\
\text { irrigation }\end{array}$ \\
\hline w11 & 5108721 & 4550112 & 9.71 & 10340 & $\mathrm{C} 4-\mathrm{S} 4$ & $\begin{array}{l}\text { Very salty - inappropriate for } \\
\text { irrigation }\end{array}$ \\
\hline w12 & 5105232 & 4548562 & 2.37 & 2590 & $\mathrm{C} 4-\mathrm{S} 1$ & $\begin{array}{l}\text { Very salty - inappropriate for } \\
\text { irrigation }\end{array}$ \\
\hline w13 & 5108871 & 4551096 & 2.12 & 2230 & $\mathrm{C} 3-\mathrm{S} 1$ & Salty - can be used for agriculture \\
\hline w14 & 5109891 & 4555971 & 2.15 & 2110 & $\mathrm{C} 3-\mathrm{S} 1$ & Salty - can be used for agriculture \\
\hline w15 & 5109820 & 4558455 & 2.02 & 3450 & $\mathrm{C} 4-\mathrm{S} 1$ & $\begin{array}{l}\text { Very salty - inappropriate for } \\
\text { irrigation }\end{array}$ \\
\hline w16 & 5108122 & 4530102 & 1.63 & 1687 & $\mathrm{C} 3-\mathrm{S} 1$ & Salty - can be used for agriculture \\
\hline w17 & 5105462 & 4543965 & 2.66 & 1728 & $\mathrm{C} 3-\mathrm{S} 1$ & Salty - can be used for agriculture \\
\hline w18 & 5107082 & 4546109 & 2.15 & 2110 & $\mathrm{C} 3-\mathrm{S} 1$ & Salty - can be used for agriculture \\
\hline w19 & 5109864 & 4540107 & 1.33 & 1351 & $\mathrm{C} 3-\mathrm{S} 1$ & Salty - can be used for agriculture \\
\hline w20 & 5110091 & 4549088 & 1.32 & 1193 & $\mathrm{C} 3-\mathrm{S} 1$ & Salty - can be used for agriculture \\
\hline w21 & 5111587 & 4545581 & 4.8 & 10240 & $\mathrm{C} 4-\mathrm{S} 3$ & $\begin{array}{l}\text { Very salty - inappropriate for } \\
\text { irrigation }\end{array}$ \\
\hline w22 & 5111802 & 4540092 & 2.41 & 2360 & $\mathrm{C} 4-\mathrm{S} 1$ & $\begin{array}{l}\text { Very salty - inappropriate for } \\
\text { irrigation }\end{array}$ \\
\hline w23 & 5111984 & 4549859 & 2.48 & 2110 & $\mathrm{C} 3-\mathrm{S} 1$ & Salty - can be used for agriculture \\
\hline w24 & 5112081 & 4553079 & 1.3 & 1190 & $\mathrm{C} 3-\mathrm{S} 1$ & Salty - can be used for agriculture \\
\hline w25 & 5114893 & 4540109 & 1.3 & 1635 & $\mathrm{C} 3-\mathrm{S} 1$ & Salty - can be used for agriculture \\
\hline w26 & 5115871 & 4549891 & 5.83 & 12650 & $\mathrm{C} 4-\mathrm{S} 3$ & $\begin{array}{l}\text { Very salty - inappropriate for } \\
\text { irrigation }\end{array}$ \\
\hline w27 & 5117909 & 4549811 & 0.78 & 567 & $\mathrm{C} 2-\mathrm{S} 1$ & $\begin{array}{l}\text { Slightly salty - suitable for } \\
\text { agriculture }\end{array}$ \\
\hline w28 & 5115086 & 4553809 & 3.42 & 1045 & $\mathrm{C} 3-\mathrm{S} 1$ & Salty - can be used for agriculture \\
\hline w29 & 5118255 & 4556857 & 0.94 & 748 & $\mathrm{C} 2-\mathrm{S} 1$ & $\begin{array}{l}\text { Slightly salty - suitable for } \\
\text { agriculture }\end{array}$ \\
\hline w30 & 5119922 & 4546823 & 1.14 & 952 & $\mathrm{C} 3-\mathrm{S} 1$ & Salty - can be used for agriculture \\
\hline w31 & 5120109 & 4547891 & 2.5 & 1720 & $\mathrm{C} 3-\mathrm{S} 1$ & Salty - can be used for agriculture \\
\hline w32 & 5119986 & 4538092 & 1.03 & 675 & $\mathrm{C} 2-\mathrm{S} 1$ & $\begin{array}{l}\text { Slightly salty - suitable for } \\
\text { agriculture }\end{array}$ \\
\hline w33 & 5124687 & 4540071 & 2.79 & 5990 & $\mathrm{C} 4-\mathrm{S} 2$ & $\begin{array}{l}\text { Very salty - inappropriate for } \\
\text { irrigation }\end{array}$ \\
\hline
\end{tabular}


Table 8 Comparison of groundwater quality parameters $\left(\mathrm{pH}, \mathrm{EC}\right.$, and $\left.\mathrm{Cl}^{-}\right)$with some of recent studies on coastal aquifers as well as the aquifers adjacent to hypersaline lakes

\begin{tabular}{lllll}
\hline Country & $\mathrm{pH}$ & $\mathrm{EC}(\mu \mathrm{S} / \mathrm{cm})$ & $\mathrm{Cl}^{-}(\mathrm{mg} / \mathrm{L})$ & Reference \\
\hline Iran & $7.61^{*}$ & $3029^{*}$ & $18.755^{*}$ & Present study \\
Palestine & 7.60 & 4189 & - & Naeem et al. (2019) \\
Bangladesh & 6.03 & 7135.67 & 2978.40 & Rakib et al. (2020) \\
Spain & 7.54 & 1540.34 & 95.83 & Mostaza-Colado et al. (2018) \\
India & 8.40 & 2616 & 705 & Umarani et al. (2019) \\
\hline
\end{tabular}

${ }^{*}$ Comparison with mean values. 
Table 9 Similarity matrix for June 2012

\begin{tabular}{|c|c|c|c|c|c|c|c|c|c|c|c|}
\hline & EC & TDS & $\mathrm{pH}$ & $\mathrm{Ca}^{2+}$ & $\mathrm{Mg}^{2+}$ & $\mathrm{Na}^{+}$ & $\mathrm{K}^{+}$ & $\mathrm{HCO}_{3}^{-}$ & $\mathrm{CO}_{3}{ }^{2-}$ & $\mathrm{Cl}^{-}$ & $\mathrm{SO}_{4}^{2-}$ \\
\hline EC & 2.35 & & & & & & & & & & \\
\hline TDS & 2.35 & 2.35 & & & & & & & & & \\
\hline $\mathrm{pH}$ & 14.678 & 14.678 & 167.099 & & & & & & & & \\
\hline $\mathrm{Ca}^{2+}$ & 2.29 & 2.29 & 14.134 & 2.255 & & & & & & & \\
\hline $\mathrm{Mg}^{2+}$ & 2.304 & 2.304 & 14.361 & 2.237 & 2.285 & & & & & & \\
\hline $\mathrm{Na}^{+}$ & 2.332 & 2.332 & 14.776 & 2.242 & 2.277 & 2.371 & & & & & \\
\hline $\mathrm{K}^{+}$ & 2.589 & 2.589 & 22.435 & 2.469 & 2.516 & 2.654 & 4.133 & & & & \\
\hline $\mathrm{HCO}_{3}^{-}$ & 3.019 & 3.019 & 29.993 & 2.896 & 2.868 & 3.136 & 4.537 & 6.618 & & & \\
\hline $\mathrm{CO}_{3}{ }^{2-}$ & 0.162 & 0.162 & 4.544 & 0.162 & 0.159 & 0.151 & 0.346 & 0.531 & 1.096 & & \\
\hline $\mathrm{Cl}^{-}$ & 1.819 & 1.819 & 9.068 & 1.787 & 1.781 & 1.785 & 1.743 & 1.893 & 0.083 & 1.521 & \\
\hline $\mathrm{SO}_{4}{ }^{2-}$ & 2.021 & 2.021 & 17.527 & 1.923 & 2.04 & 2.024 & 2.83 & 3.245 & 0.114 & 1.256 & 2.889 \\
\hline
\end{tabular}


Table 10 Similarity matrix for June 2018

\begin{tabular}{|c|c|c|c|c|c|c|c|c|c|c|c|}
\hline & $\mathrm{EC}$ & TDS & $\mathrm{pH}$ & $\mathrm{Ca}^{2+}$ & $\mathrm{Mg}^{2+}$ & $\mathrm{Na}^{+}$ & $\mathrm{K}^{+}$ & $\mathrm{HCO}_{3}{ }^{-}$ & $\mathrm{CO}_{3}{ }^{2-}$ & $\mathrm{Cl}^{-}$ & $\mathrm{SO}_{4}{ }^{2-}$ \\
\hline EC & 2.068 & & & & & & & & & & \\
\hline TDS & 2.068 & 2.069 & & & & & & & & & \\
\hline $\mathrm{pH}$ & 16.051 & 16.052 & 252.042 & & & & & & & & \\
\hline $\mathrm{Ca}^{2+}$ & 2.089 & 2.089 & 16.526 & 2.138 & & & & & & & \\
\hline $\mathrm{Mg}^{2+}$ & 1.895 & 1.895 & 14.067 & 1.938 & 1.818 & & & & & & \\
\hline $\mathrm{Na}^{+}$ & 1.821 & 1.821 & 13.036 & 1.789 & 1.629 & 1.701 & & & & & \\
\hline $\mathrm{K}^{+}$ & 2.93 & 2.931 & 33.224 & 3.011 & 2.641 & 2.412 & 5.5 & & & & \\
\hline $\mathrm{HCO}_{3}{ }^{-}$ & 2.861 & 2.861 & 39.129 & 2.982 & 2.46 & 2.287 & 5.708 & 7.321 & & & \\
\hline $\mathrm{CO}_{3}{ }^{2-}$ & 0.07 & 0.07 & 5.234 & 0.071 & 0.052 & 0.06 & 0.115 & 0.453 & 1.088 & & \\
\hline $\mathrm{Cl}^{-}$ & 1.695 & 1.695 & 10.529 & 1.705 & 1.582 & 1.517 & 2.141 & 1.877 & 0.012 & 1.465 & \\
\hline $\mathrm{SO}_{4}{ }^{2-}$ & 2.083 & 2.084 & 23.845 & 2.114 & 1.919 & 1.79 & 3.694 & 3.953 & 0.155 & 1.479 & 3.28 \\
\hline
\end{tabular}


Table 11 PCA variable loading for June 2012

\begin{tabular}{l|rrrrrrrrrrr}
\hline & Axis 1 & Axis 2 & Axis 3 & Axis 4 & Axis 5 & Axis 6 & Axis 7 & Axis 8 & Axis 9 & Axis 10 & Axis 11 \\
\hline $\mathrm{EC}$ & 0.087 & 0.374 & -0.117 & -0.03 & -0.055 & -0.032 & -0.049 & -0.059 & 0.039 & -0.571 & 0.707 \\
$\mathrm{TDS}$ & 0.087 & 0.374 & -0.117 & -0.03 & -0.055 & -0.032 & -0.049 & -0.059 & 0.039 & -0.571 & -0.707 \\
$\mathrm{pH}$ & 0.95 & -0.26 & -0.11 & 0.061 & -0.101 & 0.065 & 0.016 & -0.009 & -0.002 & 0 & 0 \\
$\mathrm{Ca}^{2+}$ & 0.084 & 0.367 & -0.15 & -0.045 & -0.098 & -0.028 & -0.617 & -0.284 & -0.492 & 0.346 & 0 \\
$\mathrm{Mg}^{2+}$ & 0.085 & 0.367 & -0.154 & 0.062 & -0.038 & -0.054 & 0.054 & 0.882 & -0.105 & 0.186 & 0 \\
$\mathrm{Na}^{+}$ & 0.088 & 0.369 & -0.03 & -0.081 & -0.009 & -0.035 & 0.774 & -0.296 & -0.342 & 0.209 & 0 \\
$\mathrm{~K}^{+}$ & 0.131 & 0.233 & 0.367 & 0.006 & 0.627 & 0.629 & -0.068 & 0.022 & -0.001 & 0.005 & 0 \\
$\mathrm{HCO}_{3}^{-}$ & 0.173 & 0.124 & 0.633 & -0.595 & -0.037 & -0.419 & -0.076 & 0.065 & 0.103 & 0.042 & 0 \\
$\mathrm{CO}_{3}^{2-}$ & 0.025 & -0.125 & -0.522 & -0.384 & 0.677 & -0.326 & -0.01 & -0.005 & 0.007 & 0.004 & 0 \\
$\mathrm{Cl}^{-}$ & 0.055 & 0.36 & -0.24 & -0.101 & -0.129 & 0.126 & -0.021 & -0.175 & 0.771 & 0.376 & 0 \\
$\mathrm{SO}_{4}^{2-}$ & 0.102 & 0.179 & 0.219 & 0.686 & 0.322 & -0.543 & -0.034 & -0.11 & 0.148 & 0.076 & 0 \\
\hline
\end{tabular}


Table 12 PCA variable loading for June 2018

\begin{tabular}{l|ccccccccccc}
\hline & Axis 1 & Axis 2 & Axis 3 & Axis 4 & Axis 5 & Axis 6 & Axis 7 & Axis 8 & Axis 9 & Axis 10 & Axis 11 \\
\hline EC & 0.064 & 0.368 & -0.116 & 0.075 & -0.04 & -0.09 & 0.027 & -0.447 & 0.361 & -0.017 & 0.707 \\
$\mathrm{TDS}$ & 0.064 & 0.368 & -0.116 & 0.075 & -0.04 & -0.09 & 0.027 & -0.447 & 0.361 & -0.017 & -0.707 \\
$\mathrm{pH}$ & 0.965 & -0.207 & -0.096 & -0.068 & -0.082 & -0.067 & -0.02 & -0.002 & -0.002 & 0 & 0 \\
$\mathrm{Ca}^{2+}$ & 0.065 & 0.367 & -0.076 & 0.109 & -0.051 & -0.001 & -0.366 & -0.185 & -0.662 & -0.484 & 0 \\
$\mathrm{Mg}^{2+}$ & 0.056 & 0.357 & -0.15 & -0.009 & -0.009 & 0.064 & -0.531 & 0.624 & 0.404 & -0.088 & 0 \\
$\mathrm{Na}^{+}$ & 0.052 & 0.345 & -0.182 & 0.019 & 0.023 & -0.321 & 0.706 & 0.397 & -0.075 & -0.283 & 0 \\
$\mathrm{~K}^{+}$ & 0.129 & 0.302 & 0.297 & -0.106 & -0.237 & 0.812 & 0.274 & 0.038 & -0.011 & -0.007 & 0 \\
$\mathrm{HCO}_{3}^{-}$ & 0.151 & 0.13 & 0.661 & 0.644 & 0.268 & -0.151 & -0.013 & 0.085 & 0.022 & 0.078 & 0 \\
$\mathrm{CO}_{3}^{2-}$ & 0.019 & -0.142 & -0.567 & 0.524 & 0.443 & 0.424 & 0.088 & -0.005 & -0.008 & 0.001 & 0 \\
$\mathrm{Cl}^{-}$ & 0.042 & 0.36 & -0.202 & 0.063 & -0.136 & -0.091 & -0.023 & 0.076 & -0.356 & 0.815 & 0 \\
$\mathrm{SO}_{4}^{2-}$ & 0.093 & 0.218 & 0.123 & -0.518 & 0.802 & 0.034 & -0.016 & -0.062 & -0.066 & 0.084 & 0 \\
\hline
\end{tabular}


Table 13 PCA case scores for June 2012

\begin{tabular}{|c|c|c|c|c|c|c|c|c|c|c|c|}
\hline Station & Axis 1 & Axis 2 & Axis 3 & Axis 4 & Axis 5 & Axis 6 & Axis 7 & Axis 8 & Axis 9 & Axis 10 & Axis 11 \\
\hline w1 & 2.362 & 0.001 & 0.119 & 0.066 & 0.03 & -0.029 & 0.029 & 0.007 & 0 & 0 & 0 \\
\hline w2 & 2.299 & -0.048 & 0.18 & -0.066 & 0.004 & -0.01 & -0.011 & 0.014 & 0.003 & 0 & 0 \\
\hline w3 & 2.581 & 1.127 & -0.27 & -0.247 & -0.171 & 0.13 & 0.046 & -0.055 & -0.01 & 0 & 0 \\
\hline w4 & 2.547 & 1.472 & -0.187 & -0.111 & -0.029 & -0.002 & 0.005 & 0.016 & 0.002 & 0 & 0 \\
\hline w5 & 2.362 & 0.302 & -0.16 & 0.195 & -0.01 & 0.064 & 0.07 & 0.055 & 0.006 & 0.001 & 0 \\
\hline w6 & 2.273 & 0.42 & -0.021 & -0.235 & -0.126 & 0.062 & -0.09 & 0.011 & 0.006 & -0.001 & 0 \\
\hline w7 & 2.28 & -0.122 & 0.054 & 0.065 & 0.015 & 0.087 & 0.033 & 0.008 & 0 & 0.001 & 0 \\
\hline w8 & 2.294 & 0.384 & 0.137 & 0.1 & 0.115 & -0.071 & -0.024 & 0.004 & 0.001 & 0 & 0 \\
\hline w9 & 2.373 & 0.335 & 0.605 & -0.406 & 0.196 & -0.035 & 0.064 & 0.014 & 0.002 & 0 & 0 \\
\hline w10 & 2.322 & -0.277 & 0.018 & 0.043 & -0.072 & 0.052 & -0.02 & -0.002 & 0.001 & 0 & 0 \\
\hline w11 & 2.41 & -0.244 & 0.109 & 0.005 & -0.005 & 0.088 & -0.028 & -0.014 & 0 & -0.001 & 0 \\
\hline w12 & 2.376 & 0.472 & 0.108 & 0.434 & 0.226 & -0.214 & -0.01 & -0.047 & -0.007 & -0.001 & 0 \\
\hline w13 & 2.428 & 0.028 & 0.088 & 0.139 & -0.02 & -0.173 & 0.019 & 0.015 & 0.002 & -0.001 & 0 \\
\hline w14 & 2.437 & 0.04 & 0.122 & 0.141 & 0.052 & -0.086 & 0.008 & 0.017 & 0.002 & 0 & 0 \\
\hline w15 & 2.394 & -0.068 & 0.071 & 0.219 & 0.067 & -0.024 & -0.007 & -0.007 & -0.001 & 0 & 0 \\
\hline w16 & 2.478 & 0.079 & -0.046 & 0.175 & -0.06 & -0.097 & -0.102 & 0.016 & 0.006 & -0.001 & 0 \\
\hline w17 & 2.621 & 0.643 & -0.142 & 0.104 & -0.005 & 0.046 & -0.036 & 0.008 & 0.002 & 0 & 0 \\
\hline w18 & 2.022 & -0.092 & 0.231 & -0.199 & -0.068 & -0.085 & -0.067 & 0.017 & 0.006 & 0 & 0 \\
\hline w19 & 2.524 & -0.583 & -0.272 & -0.076 & -0.048 & 0.032 & 0.03 & 0.008 & 0 & 0 & 0 \\
\hline w20 & 2.01 & -0.21 & 0.188 & -0.229 & -0.152 & -0.113 & -0.036 & 0.005 & 0.003 & 0 & 0 \\
\hline w21 & 2.404 & -0.064 & -0.188 & 0.228 & -0.077 & 0.079 & -0.02 & 0.03 & 0.005 & 0 & 0 \\
\hline w22 & 2.331 & -0.37 & 0.036 & -0.083 & -0.176 & -0.007 & -0.016 & 0.004 & -0.002 & -0.002 & 0 \\
\hline w23 & 2.389 & -0.117 & 0.122 & 0.1 & 0.041 & -0.002 & 0.023 & -0.049 & -0.008 & 0 & 0 \\
\hline w24 & 2.27 & -0.285 & 0.071 & -0.053 & -0.145 & -0.07 & 0.034 & -0.042 & -0.006 & 0 & 0 \\
\hline w25 & 2.628 & -0.426 & -0.531 & -0.396 & 0.47 & -0.172 & -0.018 & 0.003 & -0.001 & -0.001 & 0 \\
\hline w26 & 2.433 & -0.213 & 0.014 & 0.025 & -0.146 & -0.091 & 0.113 & 0.026 & 0.001 & 0.001 & 0 \\
\hline w27 & 2.519 & -0.44 & -0.25 & -0.003 & 0.132 & 0.027 & 0.005 & -0.002 & 0.004 & 0.002 & 0 \\
\hline w28 & 1.979 & -0.252 & 0.103 & -0.108 & -0.13 & -0.06 & -0.013 & -0.018 & -0.009 & 0.005 & 0 \\
\hline w29 & 2.349 & -0.453 & -0.049 & 0.013 & -0.169 & 0.063 & -0.001 & -0.009 & -0.001 & 0 & 0 \\
\hline w30 & 2.24 & -0.179 & 0.27 & -0.002 & 0.305 & 0.442 & -0.019 & -0.001 & 0.001 & 0 & 0 \\
\hline w31 & 2.127 & -0.159 & -0.037 & 0.201 & 0.049 & 0.147 & -0.003 & -0.008 & -0.001 & 0 & 0 \\
\hline w32 & 2.386 & -0.442 & -0.037 & 0.015 & -0.168 & 0.044 & -0.007 & -0.009 & -0.001 & 0 & 0 \\
\hline w33 & 2.467 & -0.511 & -0.203 & -0.078 & -0.002 & -0.013 & 0.027 & -0.016 & -0.004 & -0.001 & 0 \\
\hline
\end{tabular}


Table 14 PCA case scores for June 2018

\begin{tabular}{|c|c|c|c|c|c|c|c|c|c|c|c|}
\hline Station & Axis 1 & Axis 2 & Axis 3 & Axis 4 & Axis 5 & Axis 6 & Axis 7 & Axis 8 & Axis 9 & Axis 10 & Axis 11 \\
\hline w1 & 2.717 & -0.115 & 0.223 & 0.107 & -0.102 & 0.103 & 0.039 & 0.012 & -0.005 & -0.001 & 0 \\
\hline w2 & 2.95 & -0.029 & 0.124 & -0.147 & 0.126 & 0.068 & 0.024 & 0.006 & 0.012 & 0.001 & 0 \\
\hline w3 & 2.832 & 0.19 & 0.061 & 0.133 & -0.159 & 0.03 & -0.057 & -0.029 & -0.017 & -0.004 & 0 \\
\hline w4 & 3.175 & 1.251 & -0.275 & -0.098 & 0.066 & -0.021 & -0.095 & 0.036 & 0.007 & 0.008 & 0 \\
\hline w5 & 2.586 & -0.167 & 0.187 & 0.132 & -0.015 & -0.065 & -0.023 & 0.014 & 0.006 & 0.002 & 0 \\
\hline w6 & 2.614 & -0.128 & 0.074 & -0.046 & 0.028 & -0.031 & -0.021 & -0.024 & -0.019 & -0.004 & 0 \\
\hline w7 & 2.614 & -0.128 & 0.074 & -0.046 & 0.028 & -0.031 & -0.021 & -0.024 & -0.019 & -0.004 & 0 \\
\hline w8 & 2.829 & 0.184 & 0.057 & 0.133 & -0.168 & 0.031 & -0.056 & -0.03 & -0.019 & -0.004 & 0 \\
\hline w9 & 2.62 & 0.008 & 0.155 & 0.185 & 0.015 & -0.149 & -0.023 & 0 & 0.002 & 0.001 & 0 \\
\hline w10 & 2.786 & 0.385 & 0.526 & 0.228 & 0.445 & -0.049 & 0.038 & -0.019 & -0.01 & -0.005 & 0 \\
\hline w11 & 3 & 0.804 & -0.236 & 0.001 & -0.092 & -0.151 & 0.3 & -0.023 & -0.007 & -0.01 & 0 \\
\hline w12 & 2.875 & -0.033 & 0.129 & -0.12 & 0.095 & 0.076 & 0.018 & 0.009 & 0.013 & 0.002 & 0 \\
\hline w13 & 2.882 & -0.108 & 0.061 & -0.189 & 0.102 & 0.041 & 0.005 & -0.007 & 0.002 & -0.001 & 0 \\
\hline w14 & 3.034 & -0.189 & -0.031 & -0.264 & 0.121 & -0.038 & -0.023 & -0.013 & 0.002 & -0.001 & 0 \\
\hline w15 & 2.884 & 0.035 & 0.123 & 0.061 & -0.095 & 0.071 & -0.013 & 0.007 & 0.007 & 0.001 & 0 \\
\hline w16 & 2.94 & -0.306 & -0.172 & -0.265 & -0.052 & -0.077 & -0.04 & -0.027 & -0.014 & -0.003 & 0 \\
\hline w17 & 2.949 & -0.215 & -0.047 & -0.277 & 0.007 & 0.058 & 0.046 & -0.021 & -0.018 & -0.005 & 0 \\
\hline w18 & 3.034 & -0.189 & -0.031 & -0.264 & 0.121 & -0.038 & -0.023 & -0.013 & 0.002 & -0.001 & 0 \\
\hline w19 & 2.916 & -0.243 & 0.035 & -0.107 & -0.188 & 0.154 & 0.043 & 0.021 & 0.007 & 0.002 & 0 \\
\hline w20 & 2.586 & -0.274 & 0.13 & 0.117 & -0.066 & -0.105 & -0.021 & 0.016 & 0.004 & 0.002 & 0 \\
\hline w21 & 2.845 & 0.846 & -0.086 & 0.203 & -0.193 & -0.005 & -0.027 & -0.04 & -0.001 & -0.004 & 0 \\
\hline w22 & 2.938 & -0.088 & 0.151 & -0.022 & -0.013 & 0.074 & 0.032 & 0.027 & 0.02 & 0.004 & 0 \\
\hline w23 & 2.814 & -0.116 & 0.115 & -0.092 & 0.078 & 0.015 & 0.019 & 0.008 & 0.009 & 0.001 & 0 \\
\hline w24 & 2.867 & -0.335 & 0.1 & 0.095 & -0.091 & -0.124 & -0.027 & 0.015 & 0.003 & 0.002 & 0 \\
\hline w25 & 2.687 & -0.186 & 0.146 & 0.029 & -0.011 & -0.013 & -0.009 & 0.001 & -0.005 & -0.001 & 0 \\
\hline w26 & 2.894 & 1.311 & -0.247 & -0.078 & 0.09 & -0.002 & -0.089 & 0.036 & 0.007 & 0.008 & 0 \\
\hline w27 & 2.982 & -0.562 & -0.363 & 0.133 & 0.016 & 0.018 & -0.011 & 0.001 & -0.004 & 0.001 & 0 \\
\hline w28 & 3.005 & -0.498 & -0.326 & 0.163 & 0.102 & -0.045 & 0.016 & 0.013 & 0.009 & 0.003 & 0 \\
\hline w29 & 3.101 & -0.631 & -0.607 & 0.361 & 0.246 & 0.142 & 0.007 & -0.007 & -0.008 & 0 & 0 \\
\hline w30 & 2.98 & -0.373 & -0.061 & -0.139 & -0.174 & 0.012 & 0.002 & 0.011 & 0.003 & 0.001 & 0 \\
\hline w31 & 2.856 & -0.235 & 0.117 & 0.107 & -0.103 & -0.075 & 0.003 & 0.047 & 0.033 & 0.008 & 0 \\
\hline w32 & 2.705 & -0.422 & -0.056 & -0.038 & -0.122 & -0.155 & -0.04 & 0.003 & -0.002 & 0.001 & 0 \\
\hline w33 & 2.804 & 0.45 & 0.171 & 0.08 & -0.087 & 0.242 & 0.011 & -0.013 & -0.002 & -0.002 & 0 \\
\hline
\end{tabular}




\section{Supplementary Files}

This is a list of supplementary files associated with this preprint. Click to download.

- SupplementaryData.xlsx 